\title{
LEVEL II SCOUR ANALYSIS FOR BRIDGE 11 (HINETH00040011) on TOWN HIGHWAY 4 (FAS 199), crossing LEWIS CREEK, HINESBURG, VERMONT
}

U.S. Geological Survey Open-File Report 97-106

Prepared in cooperation with

VERMONT AGENCY OF TRANSPORTATION and

FEDERAL HIGHWAY ADMINISTRATION 


\section{LEVEL II SCOUR ANALYSIS FOR BRIDGE 11 (HINETH00040011) on TOWN HIGHWAY 4 (FAS 199), crossing LEWIS CREEK, HINESBURG, VERMONT \\ By MICHAEL A. IVANOFF AND RONDA L. BURNS}

U.S. Geological Survey Open-File Report 97-106

Prepared in cooperation with

VERMONT AGENCY OF TRANSPORTATION

and

FEDERAL HIGHWAY ADMINISTRATION 


\title{
U.S. DEPARTMENT OF THE INTERIOR BRUCE BABBITT, Secretary
}

\author{
U.S. GEOLOGICAL SURVEY \\ Gordon P. Eaton, Director
}

For additional information write to:

District Chief

U.S. Geological Survey 361 Commerce Way

Pembroke, NH 03275-3718
Copies of this report may be purchased from:

U.S. Geological Survey

Branch of Information Services

Open-File Reports Unit

Box 25286

Denver, CO 80225-0286 


\section{CONTENTS}

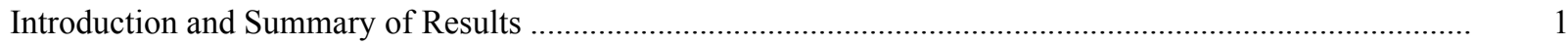

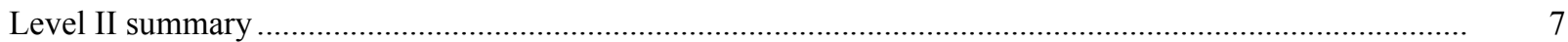

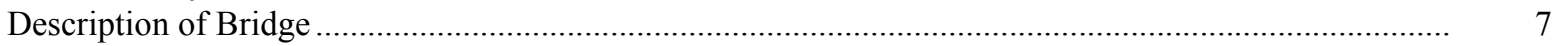

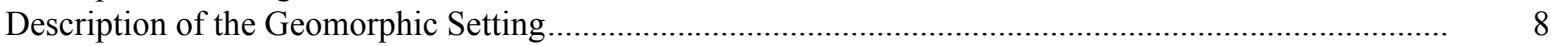

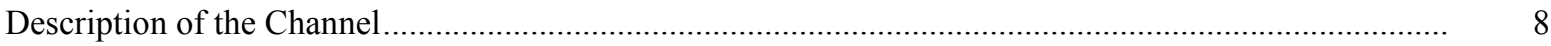

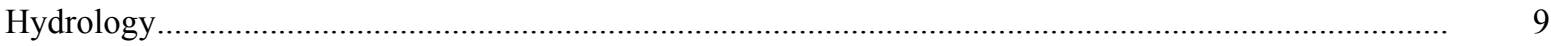

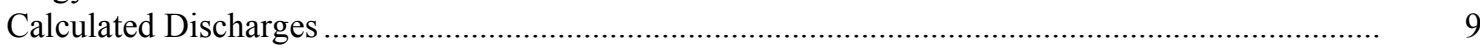

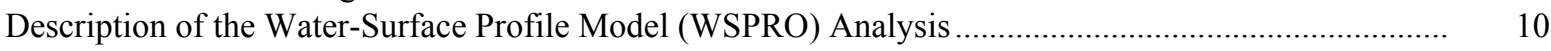

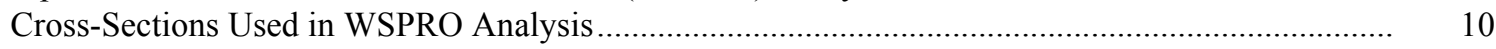

Data and Assumptions Used in WSPRO Model ..................................................................... 11

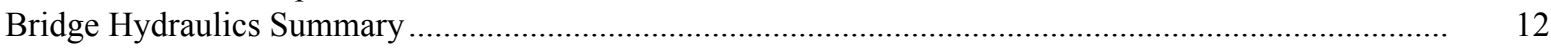

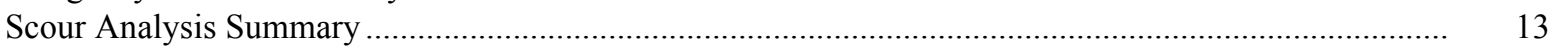

Special Conditions or Assumptions Made in Scour Analysis ...................................................... 13

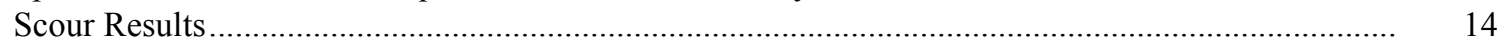

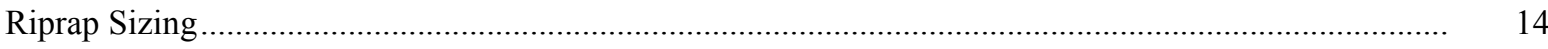

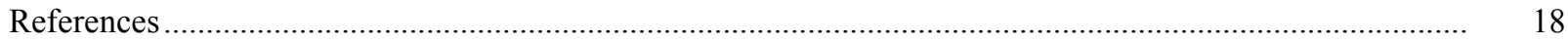

Appendixes:

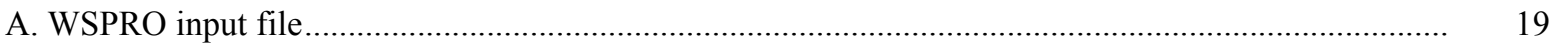

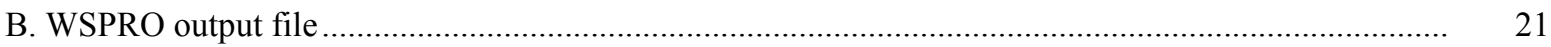

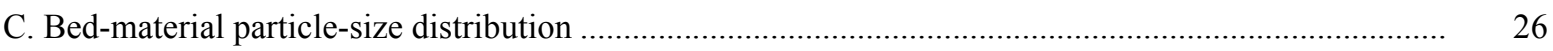

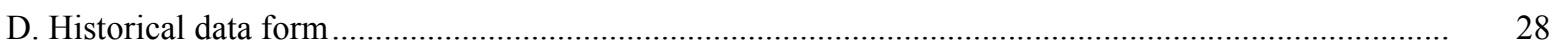

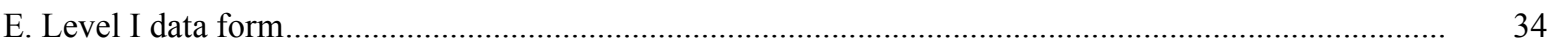

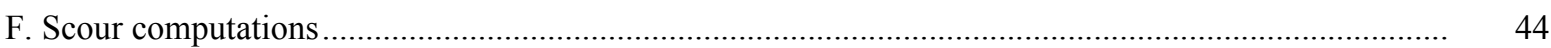

\section{FIGURES}

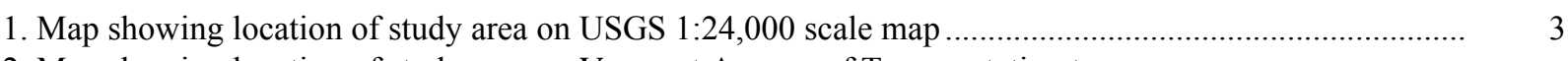

2. Map showing location of study area on Vermont Agency of Transportation town
highway map

3. Structure HINETH00040011 viewed from upstream (July 3, 1996) ......................................................

4. Downstream channel viewed from structure HINETH00040011 (July 3, 1996)................................ 5

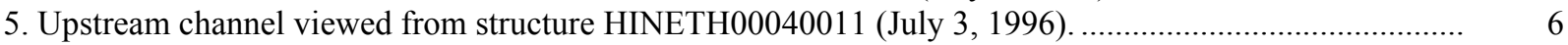

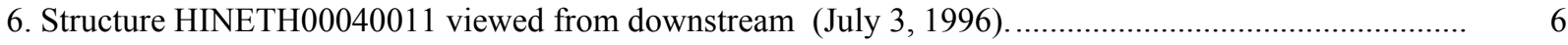

7. Water-surface profiles for the 100- and 500-year discharges at structure

HINETH00040011 on Town Highway 4, crossing Lewis Creek,

Hinesburg, Vermont.

8. Scour elevations for the 100- and 500-year discharges at structure

HINETH00040011 on Town Highway 4, crossing Lewis Creek,

Hinesburg, Vermont.

\section{TABLES}

1. Remaining footing/pile depth at abutments for the 100-year discharge at structure

HINETH00040011 on Town Highway 4, crossing Lewis Creek,

Hinesburg, Vermont.

2. Remaining footing/pile depth at abutments for the 500-year discharge at structure

HINETH00040011 on Town Highway 4, crossing Lewis Creek,

Hinesburg, Vermont...

3
5
5
6
6

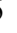




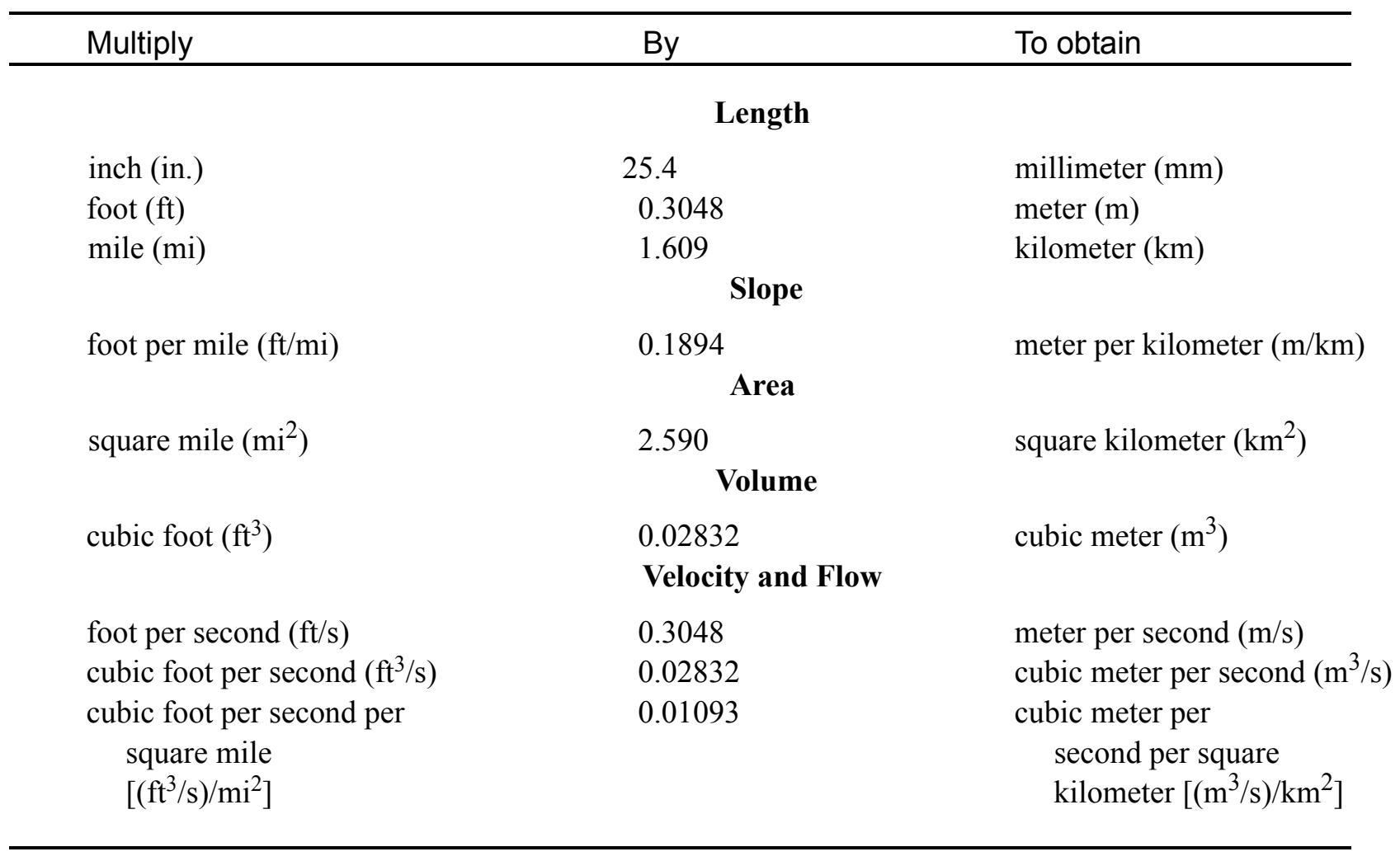

\section{OTHER ABBREVIATIONS}

$\begin{array}{lrlr}\mathrm{BF} & \text { bank full } & \text { LWW } & \text { left wingwall } \\ \mathrm{cfs} & \text { cubic feet per second } & \text { MC } & \text { main channel } \\ \mathrm{D}_{50} & \text { median diameter of bed material } & \text { RAB } & \text { right abutment } \\ \mathrm{DS} & \text { downstream } & \text { RABUT } & \text { face of right abutment } \\ \mathrm{elev} & \text { elevation } & \text { RB } & \text { right bank } \\ \mathrm{f} / \mathrm{p} & \text { flood plain } & \text { ROB } & \text { right overbank } \\ \mathrm{ft}^{2} & \text { square feet } & \text { RWW } & \text { right wingwall } \\ \mathrm{ft} / \mathrm{ft} & \text { feet per foot } & \text { TH } & \text { town highway } \\ \mathrm{JCT} & \text { junction } & \text { UB } & \text { under bridge } \\ \mathrm{LAB} & \text { left abutment } & \text { US } & \text { upstream } \\ \mathrm{LABUT} & \text { face of left abutment } & \text { USGS } & \text { United States Geological Survey } \\ \mathrm{LB} & \text { left bank } & \text { VTAOT Vermont Agency of Transportation } \\ \mathrm{LOB} & \text { left overbank } & \text { WSPRO } & \text { water-surface profile model }\end{array}$

In this report, the words "right" and "left" refer to directions that would be reported by an observer facing downstream. Sea level: In this report, "sea level" refers to the National Geodetic Vertical Datum of 1929-- a geodetic datum derived from a general adjustment of the first-order level nets of the United States and Canada, formerly called Sea Level Datum of 1929.

In the appendices, the above abbreviations may be combined. For example, USLB would represent upstream left bank. 


\title{
LEVEL II SCOUR ANALYSIS FOR BRIDGE 11 (HINETH00040011) ON TOWN HIGHWAY 4 (FAS 199), CROSSING LEWIS CREEK, HINESBURG, VERMONT
}

\author{
By Michael A. Ivanoff and Ronda L. Burns
}

\section{INTRODUCTION AND SUMMARY OF RESULTS}

This report provides the results of a detailed Level II analysis of scour potential at structure HINETH00040011 on Town Highway 4 crossing Lewis Creek, Hinesburg, Vermont (figures 1-8). A Level II study is a basic engineering analysis of the site, including a quantitative analysis of stream stability and scour (U.S. Department of Transportation, 1993). Results of a Level I scour investigation also are included in Appendix E of this report. A Level I investigation provides a qualitative geomorphic characterization of the study site. Information on the bridge, gleaned from Vermont Agency of Transportation (VTAOT) files, was compiled prior to conducting Level I and Level II analyses and is found in Appendix D.

The site is in the Green Mountain section of the New England physiographic province in northwestern Vermont. The $38.4-\mathrm{mi}^{2}$ drainage area is in a predominantly rural and forested basin. In the vicinity of the study site, the surface cover is pasture.

In the study area, Lewis Creek has an incised, straight channel with a slope of approximately $0.001 \mathrm{ft} / \mathrm{ft}$, an average channel top width of $60 \mathrm{ft}$ and an average channel depth of $7 \mathrm{ft}$. The channel bed material ranges from gravel to boulder with a median grain size $\left(D_{50}\right)$ of $47.0 \mathrm{~mm}(0.154 \mathrm{ft})$. The geomorphic assessment at the time of the Level I and Level II site visit on July 3, 1996, indicated that the reach was stable.

The Town Highway 4 crossing of Lewis Creek is an 84-foot-long, two-lane bridge consisting of one 82-foot steel-beam span (Vermont Agency of Transportation, written communication, December 15, 1995). The bridge is supported by vertical, concrete abutments with wingwalls and spill-through embankments at each abutment. The channel is skewed approximately 40 degrees to the opening while the opening-skew-to-roadway is 15 degrees. 
The scour protection measures at the site were type- 2 stone fill (less than 36 inches diameter) at the downstream left and right wingwalls and the downstream right bank. Scour protection also included type-3 stone fill (less than 48 inches diameter) at the left and right upstream wingwalls, both abutments, both upstream banks, and the left bank downstream. Additional details describing conditions at the site are included in the Level II Summary and Appendices D and E.

Scour depths and rock rip-rap sizes were computed using the general guidelines described in Hydraulic Engineering Circular 18 (Richardson and others, 1995). Total scour at a highway crossing is comprised of three components: 1) long-term streambed degradation; 2) contraction scour (due to accelerated flow caused by a reduction in flow area at a bridge) and; 3) local scour (caused by accelerated flow around piers and abutments). Total scour is the sum of the three components. Equations are available to compute depths for contraction and local scour and a summary of the results of these computations follows.

Contraction scour for all modelled flows ranged from 0.0 to $1.8 \mathrm{ft}$. The worst-case contraction scour occurred at the 500-year discharge. Left abutment scour ranged from 14.1 to $18.2 \mathrm{ft}$. Right abutment scour ranged from 9.9 to $13.4 \mathrm{ft}$. The worst-case abutment scour occurred at left abutment for the 500-year discharge. Additional information on scour depths and depths to armoring are included in the section titled "Scour Results". Scouredstreambed elevations, based on the calculated scour depths, are presented in tables 1 and 2. A cross-section of the scour computed at the bridge is presented in figure 8. Scour depths were calculated assuming an infinite depth of erosive material and a homogeneous particlesize distribution.

It is generally accepted that the Froehlich equation (abutment scour) gives "excessively conservative estimates of scour depths" (Richardson and others, 1995, p. 47). Usually, computed scour depths are evaluated in combination with other information including (but not limited to) historical performance during flood events, the geomorphic stability assessment, existing scour protection measures, and the results of the hydraulic analyses. Therefore, scour depths adopted by VTAOT may differ from the computed values documented herein. 


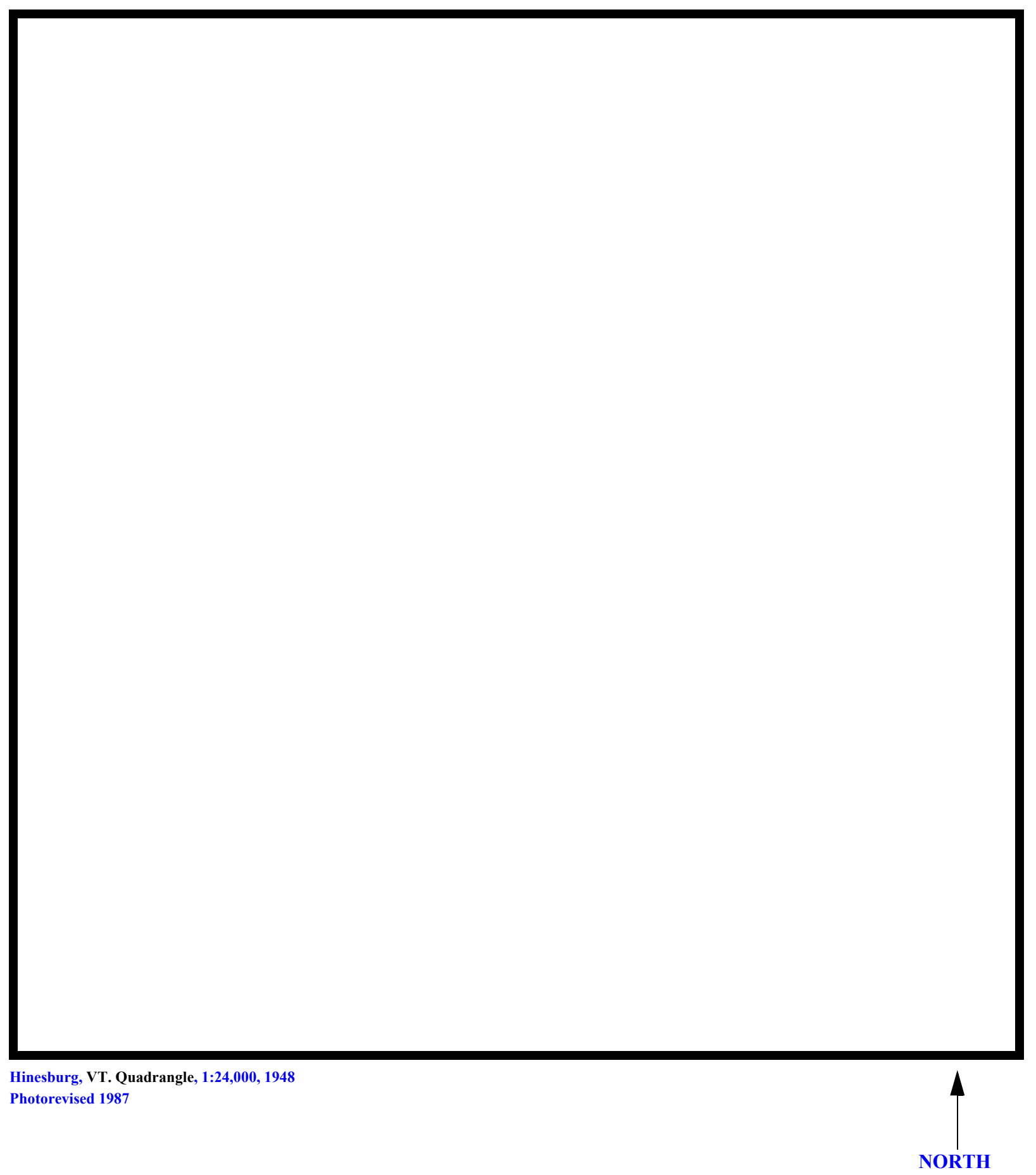

Figure 1. Location of study area on USGS 1:24,000 scale map. 
Figure 2. Location of study area on Vermont Agency of Transportation town highway map. 

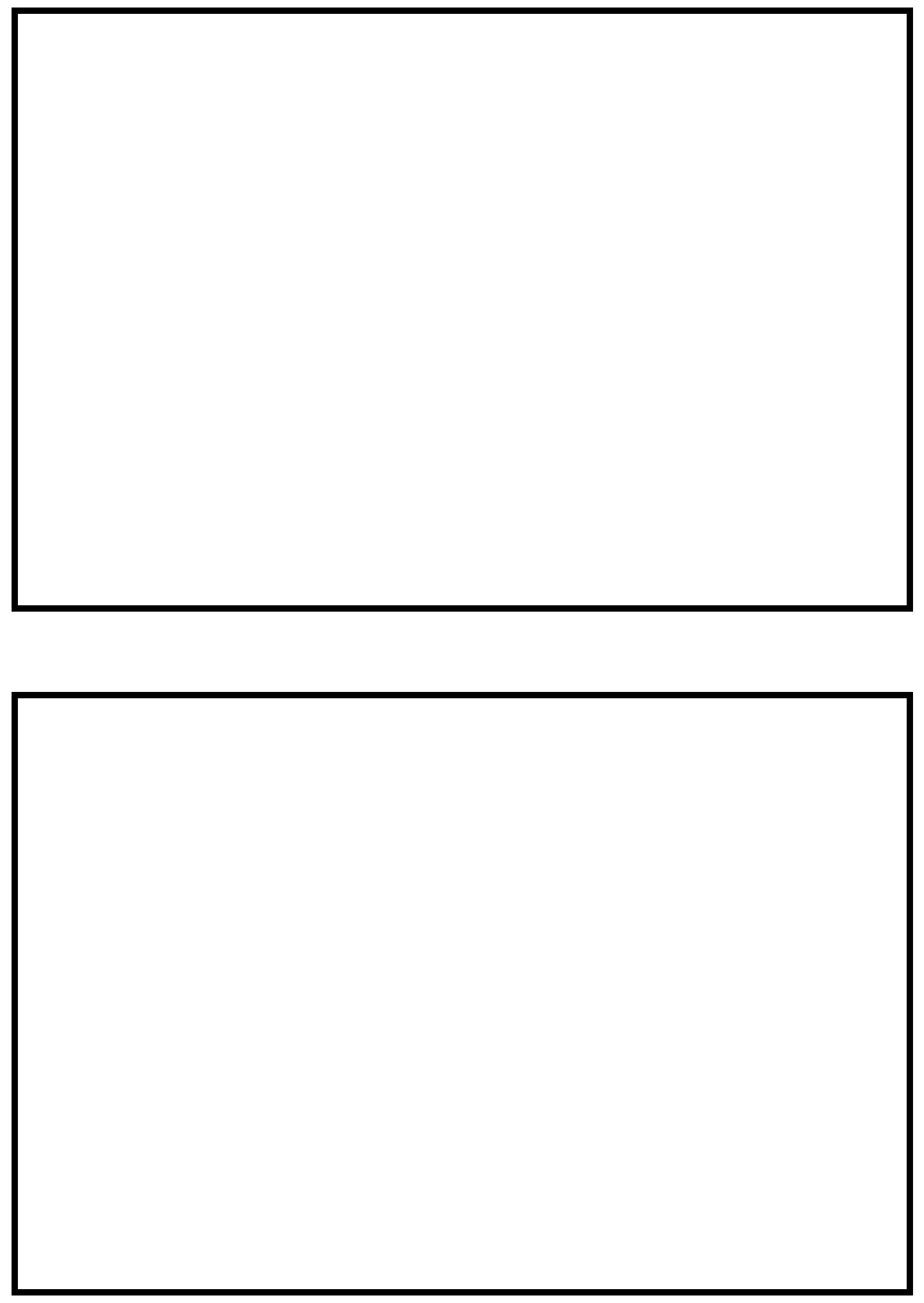


\section{LEVEL II SUMMARY}

\begin{tabular}{llllll} 
Structure Number & HINETH00040011 & & \multicolumn{2}{c}{ Lewis Creek } \\
Stream & & & & \\
County & Chittenden & Road & TH4 & District & 5
\end{tabular}

\section{Description of Bridge}

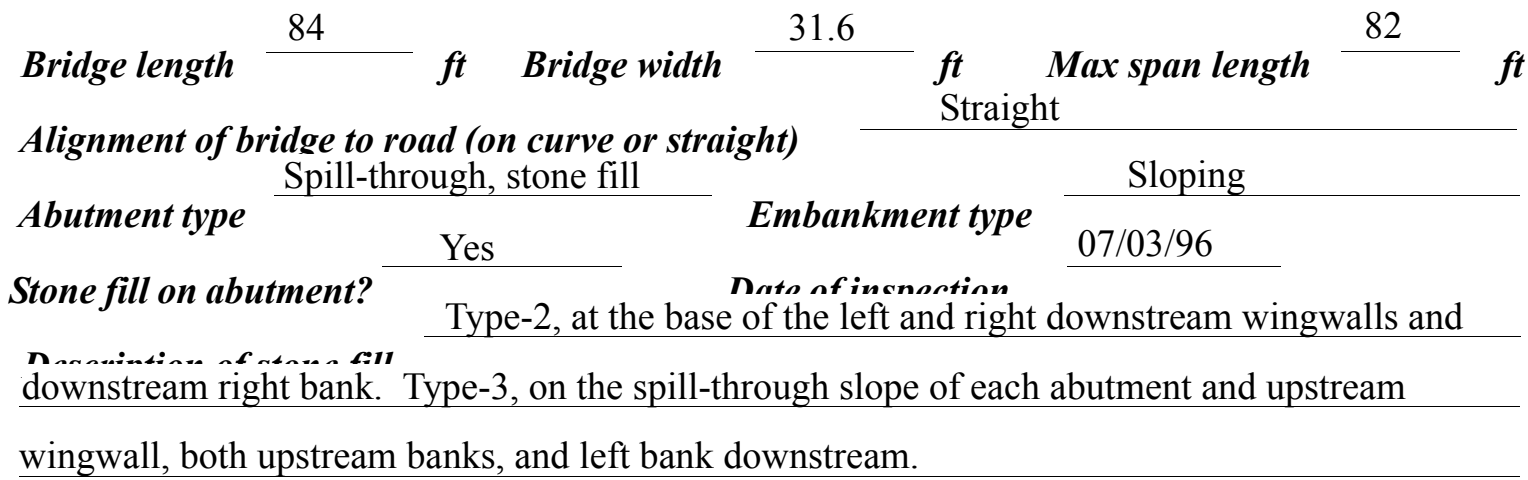

Abutments are spill-through type with stone fill

extending from the toe of the vertical, concrete part of the abutment located at the top of the bank.

Yes

$40 \quad$ Yes

Angle
Is bridge skewed to flood flow according to There ' survey?

Yes

is a mild channel bend in the upstream reach.

Debris accumulation on bridge at time of Level I or Level II site visit:

\begin{tabular}{|c|c|c|c|}
\hline & $\begin{array}{c}\text { Date of insnortion } \\
07 / 03 / 96 \\
\end{array}$ & $\begin{array}{l}\text { Percent of abmunal } \\
\text { blocked inortzontatly }\end{array}$ & $\begin{array}{l}\text { Percent of } 0 \\
\text { blocked verticatty }\end{array}$ \\
\hline & $07 / 03 / 96$ & 0 & 0 \\
\hline
\end{tabular}

Level II

Low. There is some debris caught on the stone fill at the base of the abutments and the upstream right bank.

Potential for debris

None, 07/03/96.

Doscriho anv, foaturos noar ar at tho hridos that mav, affoct flow, (includo ahsorvation dato) 


\section{Description of the Geomorphic Setting}

General topography The channel is located in a low relief valley with moderately sloping valley walls and a mild gradient bed slope.

Geomorphic conditions at bridge site: downstream (DS), upstream (US)

Date of inspection $\quad 07 / 03 / 96$

DS left: $\quad$ Moderately sloped valley wall

DS right: Moderately sloped channel bank to a narrow overbank

US left: $\quad$ Moderately sloped valley wall

US right: $\quad$ Moderately sloped channel bank to a narrow overbank

\section{Description of the Channel}

\begin{tabular}{|c|c|c|c|}
\hline \multirow[b]{2}{*}{ Average top width } & 60.0 & \multirow[b]{2}{*}{ Average depth } & 7.0 \\
\hline & Gravel to Boulders & & Silt/sand \\
\hline \multicolumn{2}{|c|}{ Predominant bed material } & Bank material & Straight and stable \\
\hline with semi-alluvial ch & poundaries. & 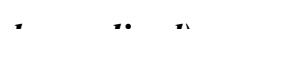 & \\
\hline
\end{tabular}

Vegetative co ${ }^{\text {Pasture }} \quad \ldots \quad \ldots \quad \ldots$
DS left: $\quad$ Pasture
DS right: $\quad$ Pasture
US left: $\quad$ Some brush and trees on immediate channel bank with pasture beyond
US right:
Do banks appear stable? - $\quad$ Yes
date of observatton.

None 07/03/96

Describe any obstructions in channel and date of observation. 


\section{Hydrology}

Drainage area $\quad 38.0 \quad \mathrm{mi}^{2}$

Percentage of drainage area in physiographic provinces: (approximate)

Physiographic province/section

New England/ Green Mountain
Percent of drainage area 100

Is drainage area considered rural or urban? — Rural _ Describe any significant urbanization:

Is there a USGS gage on the stream of interest?

No

USGS gage description

USGS gage number

Gage drainage area $\mathrm{mi}^{2}$

Is there a lake/p

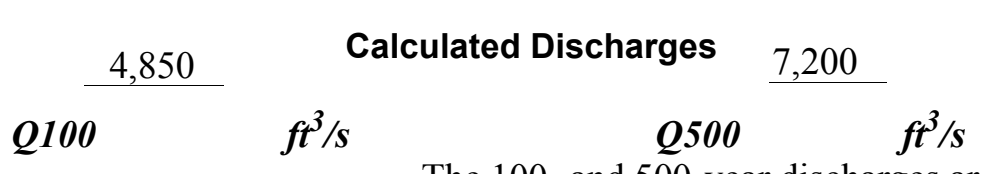

The 100- and 500-year discharges are the median

values based on a comparison of empirical methods (Benson, 1962; Johnson and Tasker, 1974;

FHWA, 1983; Potter, 1957a\&b; Talbot, 1887). 


\section{Description of the Water-Surface Profile Model (WSPRO) Analysis}

Datum for WSPRO analysis (USGS survey, sea level, VTAOT plans)

USGS survey

Datum tie between USGS survey and VTAOT plans

Add $0.3 \mathrm{ft}$. to USGS survey to

obtain VTAOT plans' datum.

Description of reference marks used to determine USGS datum. $\quad$ RM1 is a State of

Vermont survey mark, set in the top of the upstream end of the left abutment (elev. $498.74 \mathrm{ft}$,

arbitrary survey datum). RM2 is a chiseled $\mathrm{X}$ on top of the downstream end of the right

abutment (elev. $498.13 \mathrm{ft}$, arbitrary survey datum). RM3 is a chiseled X on top of the upstream

end of the right abutment (elev. $497.50 \mathrm{ft}$, arbitrary survey datum).

\section{Cross-Sections Used in WSPRO Analysis}

\begin{tabular}{cccl}
\hline${ }^{1}$ Cross-section & $\begin{array}{c}\text { Section } \\
\text { Reference } \\
\text { Distance } \\
\text { (SRD) } \text { in feet }\end{array}$ & $\begin{array}{c}{ }^{2} \text { Cross-section } \\
\text { development }\end{array}$ & \multicolumn{1}{c}{ Comments } \\
\hline EXITX & -87 & 1 & $\begin{array}{l}\text { Exit section } \\
\text { Downstream Full-valley } \\
\text { section (Templated from } \\
\text { FULLV }\end{array}$ \\
BRIDG & 0 & 2 & $\begin{array}{l}\text { BXididge section } \\
\text { Road Grade section }\end{array}$ \\
RDWAY & 20 & 1 & $\begin{array}{l}\text { Approach section as } \\
\text { surveyed }\end{array}$ \\
\hline
\end{tabular}

${ }^{1}$ For location of cross-sections see plan-view sketch included with Level I field form, Appendix E. For more detail on how cross-sections were developed see WSPRO input file. 


\section{Data and Assumptions Used in WSPRO Model}

Hydraulic analyses of the reach were done by use of the Federal Highway Administration's WSPRO step-backwater computer program (Shearman and others, 1986, and Shearman, 1990). The analyses reported herein reflect conditions existing at the site at the time of the study. Furthermore, in the development of the model it was necessary to assume no accumulation of debris or ice at the site. Results of the hydraulic model are presented in the Bridge Hydraulic Summary, Appendix B, and figure 7.

Channel roughness factors (Manning's “ $n$ ”) used in the hydraulic model were estimated using field inspections at each cross section following the general guidelines described by Arcement and Schneider (1989). Final adjustments to the values were made during the modelling of the reach. Channel " $n$ " values for the reach ranged from 0.040 to 0.046 , and overbank " $n$ " values ranged from 0.025 to 0.037 .

Normal depth at the exit section (EXITX) was assumed as the starting water surface. This depth was computed by use of the slope-conveyance method outlined in the user's manual for WSPRO (Shearman, 1990). The slope used was $0.001 \mathrm{ft} / \mathrm{ft}$ which was from surveyed thalweg points downstream of the exit section.

The approach section (APPRO) was surveyed one bridge length upstream of the upstream face as recommended by Shearman and others (1986). This approach also provides a consistent method for determining scour variables. 


\section{Bridge Hydraulics Summary}

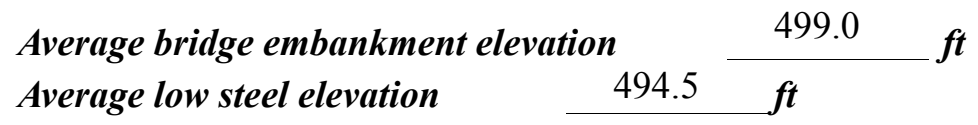

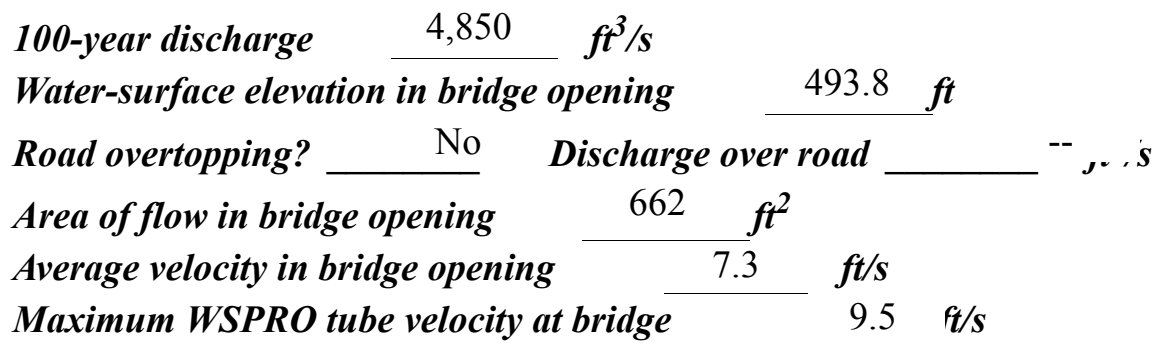

Water-surface elevation at Approach section with bridge Water-surface elevation at Approach section without bridge

Amount of backwater caused by bridge
494.5

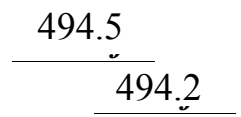

0.3 it

500-year discharge $\quad 7,200 \quad \mathrm{ft}^{3} / \mathrm{s}$

Water-surface elevation in bridge opening $495.3 \boldsymbol{f t}$

Road overtopping? ___ No Discharge over road __ - - $\quad 3 / s$

Area of flow in bridge opening $\quad 715 \quad \mathrm{ft}^{2}$

Average velocity in bridge opening $10.1 \mathrm{ft} / \mathrm{s}$

Maximum WSPRO tube velocity at bridge 12.5 , 's

Water-surface elevation at Approach section with bridge 498.0

Water-surface elevation at Approach section without bridge $\quad 495.8$

Amount of backwater caused by bridge 2.2 .

Incipient overtopping discharge ___ -- $\mathrm{ft}^{3} / \mathrm{s}$

Water-surface elevation in bridge opening $\quad--t_{t}$

Area of flow in bridge opening _ _-- $\mathrm{ft}^{2}$

Average velocity in bridge opening __ -- $f t / s$

Maximum WSPRO tube velocity at bridge _ -- $\mathrm{ft} / \mathrm{s}$

Water-surface elevation at Approach section with bridge

Water-surface elevation at Approach section without bridge

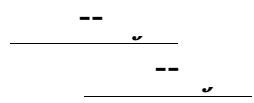
Amount of backwater caused by bridge _ 


\section{Scour Analysis Summary}

\section{Special Conditions or Assumptions Made in Scour Analysis}

Scour depths were computed using the general guidelines described in Hydraulic Engineering Circular 18 (Richardson and others, 1995). Scour depths were calculated assuming an infinite depth of erosive material and a homogeneous particle-size distribution. The results of the scour analysis are presented in tables 1 and 2 and a graph of the scour depths is presented in figure 8 .

Contraction scour for the 100-year discharge was computed by use of Laursen's clear-water contraction scour equation (Richardson and others, 1995, p. 32, equation 20). The 500-year discharge resulted in submerged orifice flow. Contraction scour at bridges with orifice flow is best estimated by use of the Chang pressure-flow scour equation (oral communication, J. Sterling Jones, October 4, 1996). Thus, contraction scour for the 500 -year discharge was computed by use of the Chang equation (Richardson and others, 1995, p. 145146). The results of Laursen's clear-water contraction scour for this event were also computed and can be found in appendix F.

Abutment scour was computed by use of the Froehlich equation (Richardson and others, 1995, p. 48, equation 28). Variables for the Froehlich equation include the Froude number of the flow approaching the embankments, the length of the embankment blocking flow, and the depth of flow approaching the embankment less any roadway overtopping.

Because the influence of scour processes on the spill-through embankment material is uncertain, the scour depth at the vertical concrete abutment walls is unknown. Therefore, the total scour depth computed at the toe of each abutment was applied to the entire area of the embankment, as shown in figure 8 . 


\section{Scour Results}

100-yr discharge 500-yr discharge

Incipient

Contraction scour:

(Scour depths in feet)

Main channel

$$
\begin{aligned}
& \text { Live-bed scour } \\
& \text { Clear-water scour } \\
& \text { Depth to armoring }
\end{aligned}
$$

Left overbank

Right overbank

Local scour:

Abutment scour

Left abutment

14.1

18.2

9.9

13.4

overtopping

discharge

\section{Right abutment}

Pier scour

Pier 1

Pier 2

Pier 3

Abutments:

Left abutment

Right abutment

Piers:

Pier 1

Pier 2

\section{Riprap Sizing}

Incipient overtopping 100-yr discharge 500-yrdischarge discharge

1.2

1.2

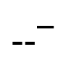

$--$

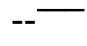
( $D_{50}$ in feet)
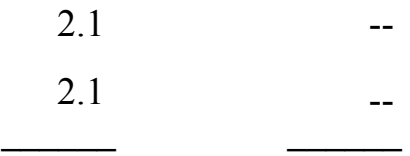

$-{ }^{-}$

$-{ }^{-}$

$--$

$--$ 


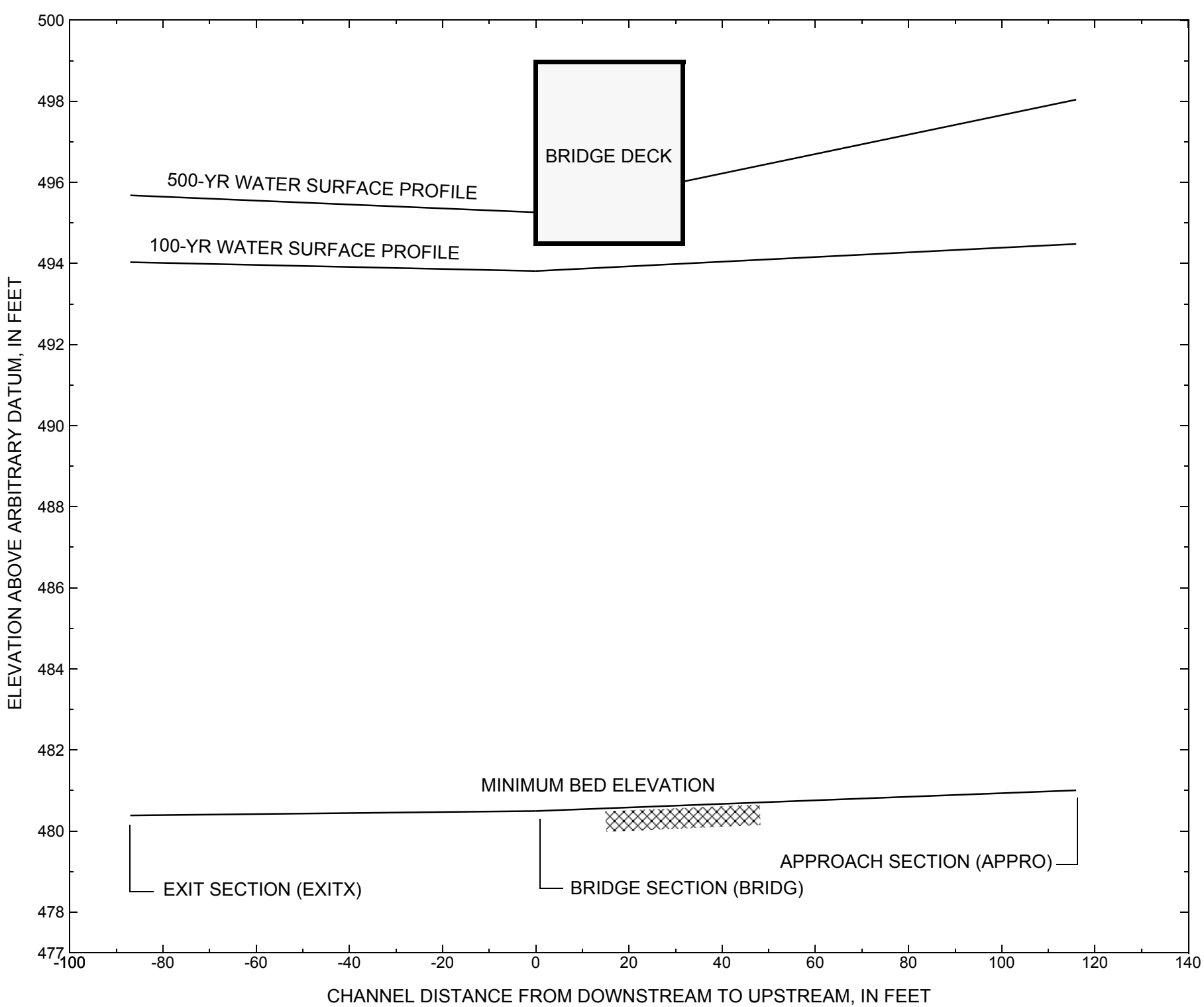

Figure 7. Water-surface profiles for the 100- and 500-yr discharges at structure HINETH00040011 on Town Highway 4, crossing Lewis Creek, Hinesburg, Vermont. 


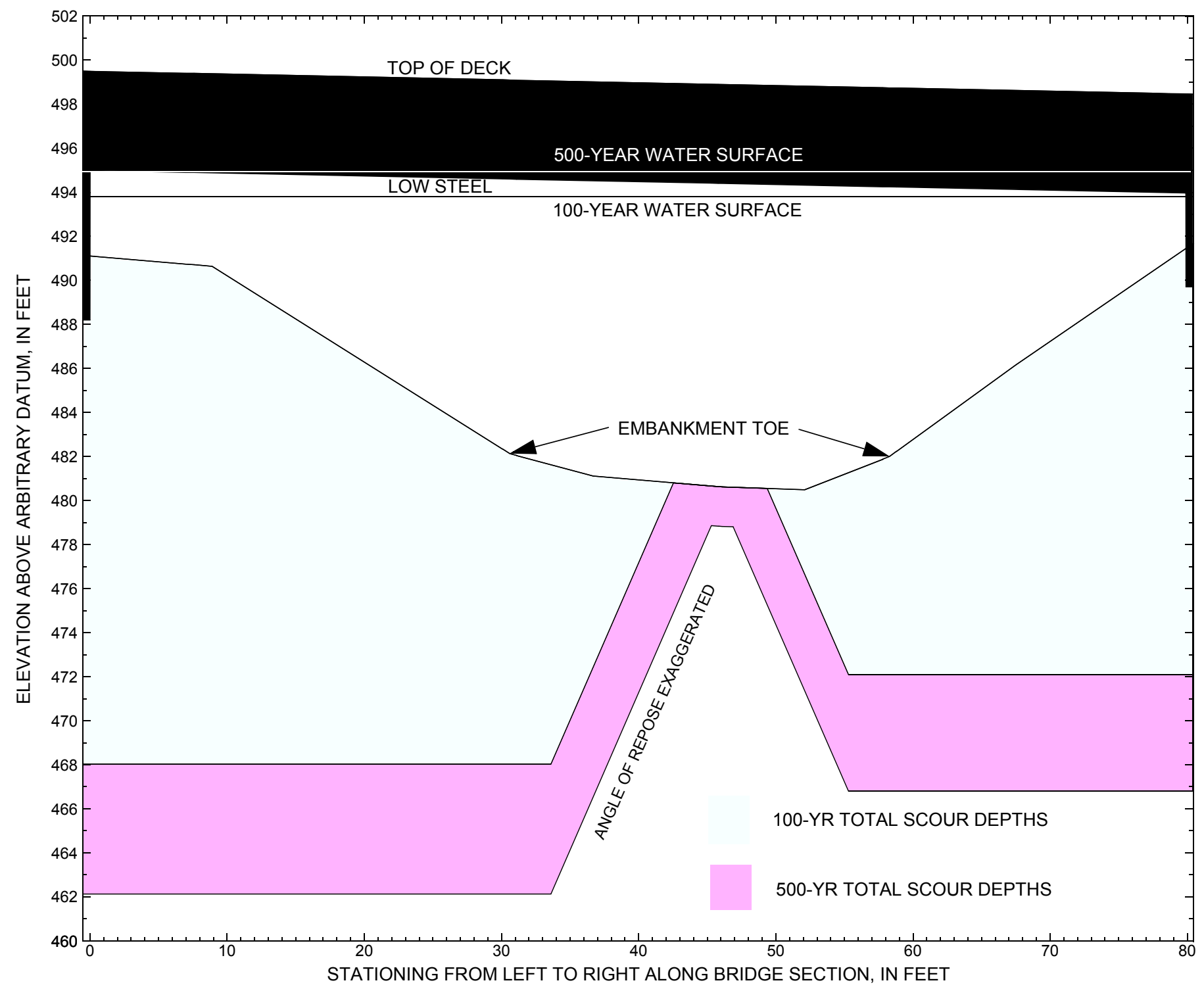

Figure 8. Scour elevations for the 100-yr and 500-yr discharges at structure HINETH00040011 on Town Highway 4, crossing Lewis Creek, Hinesburg, Vermont. 
Table 1. Remaining footing/pile depth at abutments for the 100-year discharge at structure HINETH00040011 on Town Highway 4, crossing Lewis Creek, Hinesburg, Vermont. [VTAOT, Vermont Agency of Transportation; --,no data]

\begin{tabular}{|c|c|c|c|c|c|c|c|c|c|c|c|}
\hline Description & Station $^{1}$ & $\begin{array}{l}\text { VTAOT } \\
\text { minimum } \\
\text { low-chord } \\
\text { elevation } \\
\text { (feet) }\end{array}$ & $\begin{array}{l}\text { Surveyed } \\
\text { minimum } \\
\text { low-chord } \\
\text { elevation } \\
\text { (feet) }\end{array}$ & $\begin{array}{l}\text { Bottom of } \\
\text { footing } \\
\text { elevation } \\
\text { (feet) }\end{array}$ & $\begin{array}{c}\text { Channel } \\
\text { elevation at } \\
\text { abutment/ } \\
\text { pier }^{2} \\
\text { (feet) }\end{array}$ & $\begin{array}{l}\text { Contraction } \\
\text { scour depth } \\
\text { (feet) }\end{array}$ & $\begin{array}{l}\text { Abutment } \\
\text { scour } \\
\text { depth } \\
\text { (feet) }\end{array}$ & $\begin{array}{l}\text { Pier } \\
\text { scour } \\
\text { depth } \\
\text { (feet) }\end{array}$ & $\begin{array}{l}\text { Depth of } \\
\text { total scour } \\
\text { (feet) }\end{array}$ & $\begin{array}{c}\text { Elevation of } \\
\text { scour }^{2} \\
\text { (feet) }\end{array}$ & $\begin{array}{c}\text { Remaining } \\
\text { footing/pile } \\
\text { depth } \\
\text { (feet) }\end{array}$ \\
\hline \multicolumn{12}{|c|}{100 -yr. discharge is 4,850 cubic-feet per second } \\
\hline Left abutment & 0.0 & -- & 495.3 & 488.2 & 491.1 & -- & -- & -- & -- & -- & -20.2 \\
\hline Left embankment toe & 31.1 & -- & -- & -- & 482.1 & 0.0 & 14.1 & -- & 14.1 & 468.0 & -- \\
\hline Right embankment toe & 57.8 & -- & -- & -- & 482.0 & 0.0 & 9.9 & -- & 9.9 & 472.1 & -- \\
\hline Right abutment & 79.9 & -- & 493.7 & 489.7 & 491.7 & -- & -- & -- & -- & -- & -17.6 \\
\hline
\end{tabular}

1.Measured along the face of the most constricting side of the bridge.

2.Arbitrary datum for this study.

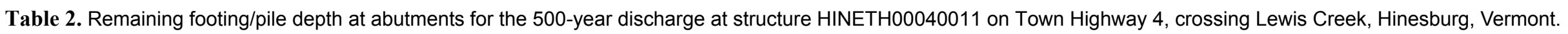
[VTAOT, Vermont Agency of Transportation; --, no data]

\begin{tabular}{|c|c|c|c|c|c|c|c|c|c|c|c|}
\hline Description & Station $^{1}$ & $\begin{array}{l}\text { VTAOT } \\
\text { minimum } \\
\text { low-chord } \\
\text { elevation } \\
\text { (feet) }\end{array}$ & $\begin{array}{l}\text { Surveyed } \\
\text { minimum } \\
\text { low-chord } \\
\text { elevation } \\
\text { (feet) }\end{array}$ & $\begin{array}{c}\text { Bottom of } \\
\text { footing } \\
\text { elevation } \\
\text { (feet) }\end{array}$ & $\begin{array}{l}\text { Channel } \\
\text { elevation at } \\
\text { abutment/ } \\
\text { pier }^{2} \\
\text { (feet) }\end{array}$ & $\begin{array}{l}\text { Contraction } \\
\text { scour depth } \\
\text { (feet) }\end{array}$ & $\begin{array}{l}\text { Abutment } \\
\text { scour } \\
\text { depth } \\
\text { (feet) }\end{array}$ & $\begin{array}{l}\text { Pier } \\
\text { scour } \\
\text { depth } \\
\text { (feet) }\end{array}$ & $\begin{array}{l}\text { Depth of } \\
\text { total scour } \\
\text { (feet) }\end{array}$ & $\begin{array}{c}\text { Elevation of } \\
\text { scour }^{2} \\
\text { (feet) }\end{array}$ & $\begin{array}{c}\text { Remaining } \\
\text { footing/pile } \\
\text { depth } \\
\text { (feet) }\end{array}$ \\
\hline \multicolumn{12}{|c|}{500 -yr. discharge is 7,200 cubic-feet per second } \\
\hline Left abutment & 0.0 & -- & 495.3 & 488.2 & 491.1 & -- & -- & -- & -- & -- & -26.1 \\
\hline Left embankment toe & 31.1 & -- & -- & -- & 482.1 & 1.8 & 18.2 & -- & 20.0 & 462.1 & -- \\
\hline Right embankment toe & 57.8 & -- & -- & -- & 482.0 & 1.8 & 13.4 & -- & 15.2 & 466.8 & -- \\
\hline Right abutment & 79.9 & -- & 493.7 & 489.7 & 491.7 & -- & -- & -- & -- & -- & -22.9 \\
\hline
\end{tabular}

1.Measured along the face of the most constricting side of the bridge.

2.Arbitrary datum for this study. 


\section{SELECTED REFERENCES}

Arcement, G.J., Jr., and Schneider, V.R., 1989, Guide for selecting Manning's roughness coefficients for natural channels and flood plains: U.S. Geological Survey Water-Supply Paper 2339, 38 p.

Barnes, H.H., Jr., 1967, Roughness characteristics of natural channels: U.S. Geological Survey Water-Supply Paper 1849,213 p.

Benson, M. A., 1962, Factors Influencing the Occurrence of Floods in a Humid Region of Diverse Terrain: U.S. Geological Survey WaterSupply Paper 1580-B, 64 p.

Brown, S.A. and Clyde, E.S., 1989, Design of riprap revetment: Federal Highway Administration Hydraulic Engineering Circular No. 11, Publication FHWA-IP-89-016, 156 p.

Federal Highway Administration, 1983, Runoff estimates for small watersheds and development of sound design: Federal Highway Administration Report FHWA-RD-77-158

Froehlich, D.C., 1989, Local scour at bridge abutments in Ports, M.A., ed., Hydraulic Engineering--Proceedings of the 1989 National Conference on Hydraulic Engineering: New York, American Society of Civil Engineers, p. 13-18.

Hayes, D.C.,1993, Site selection and collection of bridge-scour data in Delaware, Maryland, and Virginia: U.S. Geological Survey WaterResources Investigation Report 93-4017, 23 p.

Interagency Advisory Committee on Water Data, 1982, Guidelines for determining flood flow frequency: U.S. Geological Survey, Bulletin 17B of the Hydrology Subcommittee, 190 p.

Johnson, C.G. and Tasker, G.D.,1974, Progress report on flood magnitude and frequency of Vermont streams: U.S. Geological Survey OpenFile Report 74-130, 37 p.

Lagasse, P.F., Schall, J.D., Johnson, F., Richardson, E.V., Chang, F., 1995, Stream Stability at Highway Structures: Federal Highway Administration Hydraulic Engineering Circular No. 20, Publication FHWA-IP-90-014, 144 p.

Laursen, E.M., 1960, Scour at bridge crossings: Journal of the Hydraulics Division, American Society of Civil Engineers, v. 86, no. HY2, p. 39-53.

Potter, W. D., 1957a, Peak rates of runoff in the Adirondack, White Mountains, and Maine woods area, Bureau of Public Roads

Potter, W. D., 1957b, Peak rates of runoff in the New England Hill and Lowland area, Bureau of Public Roads

Richardson, E.V. and Davis, S.R., 1995, Evaluating scour at bridges: Federal Highway Administration Hydraulic Engineering Circular No. 18, Publication FHWA-IP-90-017, 204 p.

Richardson, E.V., Simons, D.B., and Julien, P.Y., 1990, Highways in the river environment: Federal Highway Administration Publication FHWA-HI-90-016.

Ritter, D.F., 1984, Process Geomorphology: W.C. Brown Co., Debuque, Iowa, 603 p.

Shearman, J.O., 1990, User's manual for WSPRO--a computer model for water surface profile computations: Federal Highway Administration Publication FHWA-IP-89-027, 187 p.

Shearman, J.O., Kirby, W.H., Schneider, V.R., and Flippo, H.N., 1986, Bridge waterways analysis model; research report: Federal Highway Administration Publication FHWA-RD-86-108, 112 p.

Talbot, A.N., 1887, The determination of water-way for bridges and culverts.

U.S. Department of Transportation, 1993, Stream stability and scour at highway bridges, Participant Workbook: Federal Highway Administration Publication FHWA HI-91-011.

U.S. Geological Survey, 1948, Hinesburg, Vermont 7.5 Minute Series quadrangle map: U.S. Geological Survey Topographic Maps, Photorevised 1987, Scale 1:24,000. 


\section{APPENDIX A: \\ WSPRO INPUT FILE}




\section{WSPRO INPUT FILE}

*

$\mathrm{XS}$

GR

GR

GR

GR

GR

$\mathrm{N}$

SA

*

XS

*

*

BR

GR

GR

GR

*

CD

$\mathrm{N}$

*

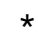

XR

GR

GR

GR

*

AS

GR

GR

GR

GR

GR

$\mathrm{N}$

SA

HP 1 BRIDG

HP 2 BRIDG

HP 1 APPRO

HP 2 APPRO

*

HP 1 BRIDG

HP 2 BRIDG

HP 1 APPRO

HP 2 APPRO

FULLV
U.S. Geological Survey WSPRO Input File hine011.wsp Hydraulic analysis for structure HINETH00040011 Date: 29-0CT-96 Bridge \# 11 over Lewis Creek in Hinesburg, VT by MAI

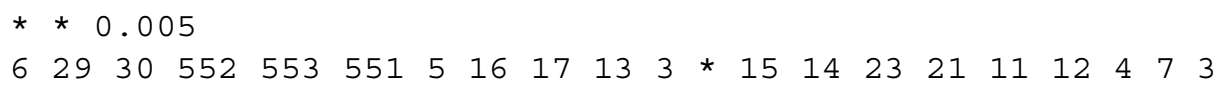

0.0

0.037

55.0

$0 * \star \star * 0.0022$

\section{SRD LSEL XSSKEW}

$\begin{array}{lll}0 & 494.49 & 15.0\end{array}$

$0.0,495.26 \quad 0.0,491.13$

$36.7,481.11$

$45.8,480.63$

$8.9,490.64$

$31.1,482.13$

$67.5,486.16$

$79.6,491.66$

$52.1,480.49$

$79.9,493.72$

$57.8,482.00$

$0.0,495.26$

BRTYPE BRWDTH EMBSS EMBELV WWANGL WWWID

$\begin{array}{llllll}1 & 46.9 & * & * & 64.5 & 9.3\end{array}$

0.040

$\begin{array}{rrrrrr}\text { SRD } & \text { EMBWID } & \text { IPAVE } \\ 20 & 31.6 & 1 & & & \\ -494.4, & 535.73 & -385.6, & 525.37 & -297.9,517.25 & -176.5,507.80 \\ -77.1,502.43 & 0.0,499.75 & 80.0,498.21 & 195.7,498.42 \\ 346.7, & 502.81 & 665.2,525.02 & & \end{array}$

116

\begin{tabular}{|c|c|c|c|c|c|c|c|}
\hline-243.1 & 517.17 & -118.0, & 506.67 & -64.5 & 503.45 & -52.4 & 502.07 \\
\hline-16.0 & 489.21 & 16.0 & 487.57 & 26.7 & 486.19 & 32.8 & 483.39 \\
\hline 36.6 & 482.52 & 38.9, & 481.88 & 49.8 & 481.73 & 57.8, & 481.00 \\
\hline 62.5 & 481.31 & 67.9, & 481.61 & 69.1, & 482.59 & 87.9, & 495.53 \\
\hline 145.8, & 498.17 & 360.0 & 501.07 & 424.3 & 506.64 & 555.2, & 527.13 \\
\hline 0.030 & \multicolumn{2}{|c|}{0.046} & 0.025 & & & & \\
\hline & 26.7 & & & & & & \\
\hline
\end{tabular}

493.811493 .81

$493.81 * * 4850$

$494.48 \quad 1 \quad 494.48$

494.48 * 4850

$495.26 \quad 1495.26$

$495.26 * * 7200$

498.041498 .04

498.04 * 7200 


\section{APPENDIX B: \\ WSPRO OUTPUT FILE}


WSPRO OUTPUT FILE

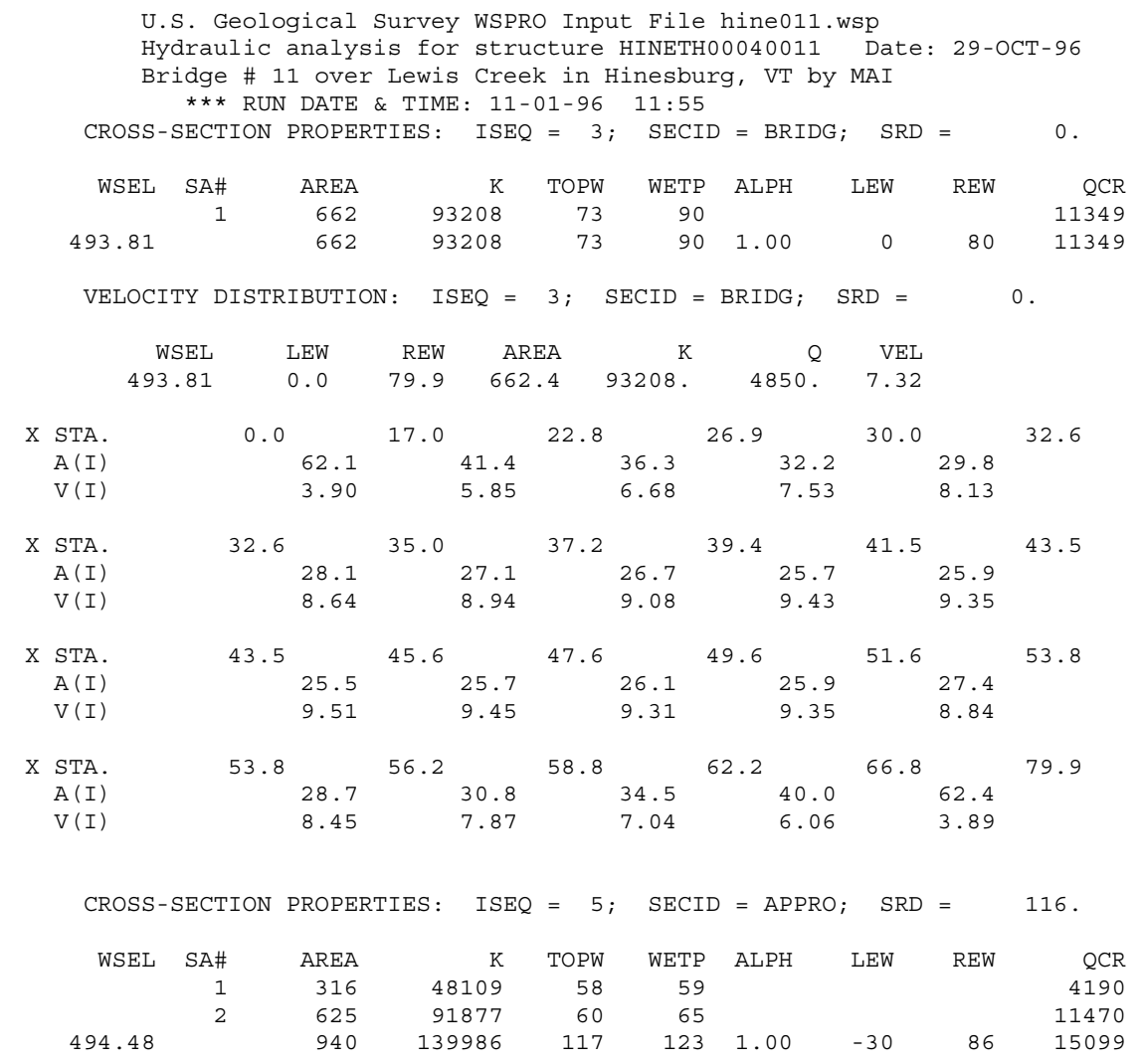

VELOCITY DISTRIBUTION: ISEQ $=5 ;$ SECID $=$ APPRO $; \quad$ SRD $=116$.

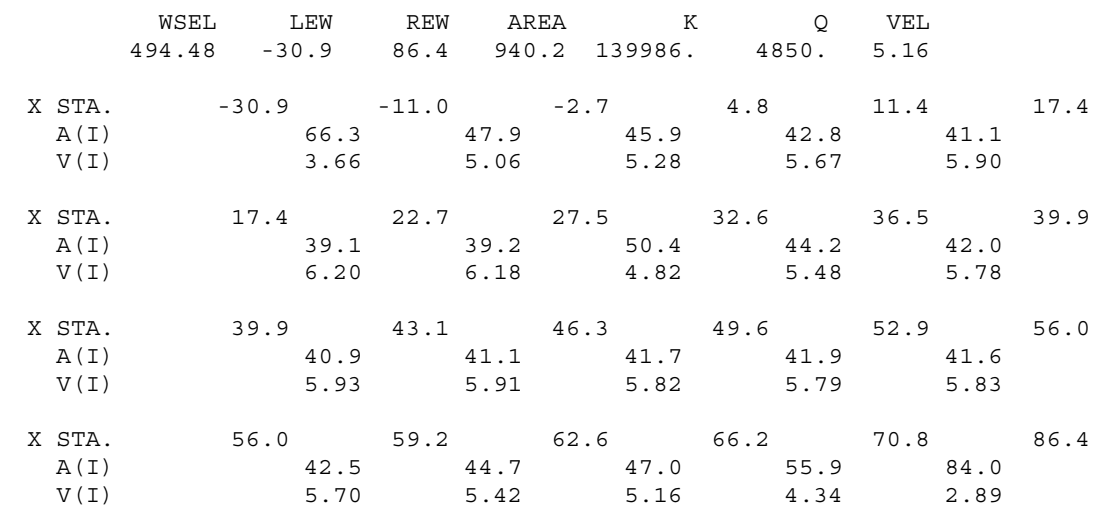


WSPRO OUTPUT FILE (continued)

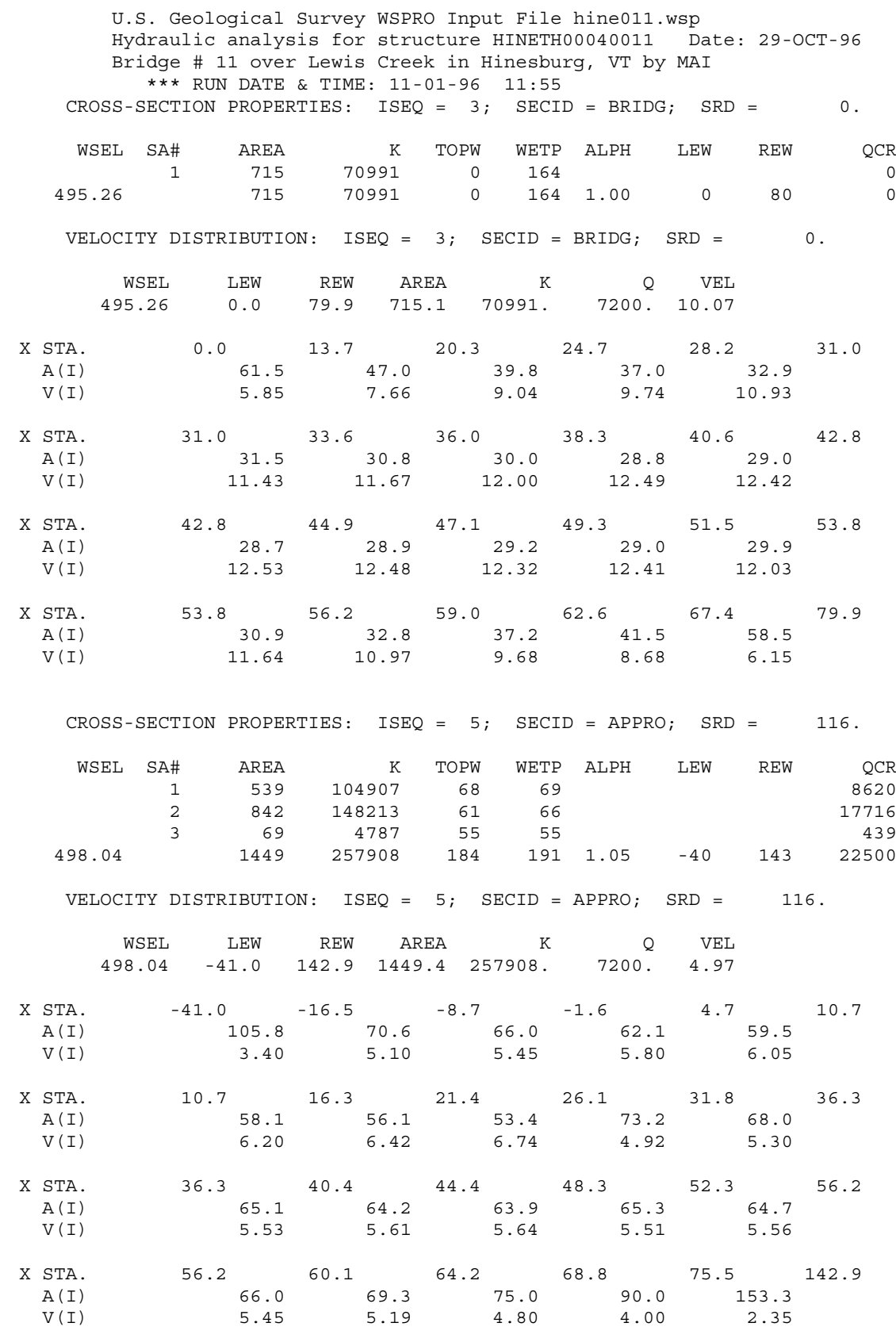


WSPRO OUTPUT FILE (continued)

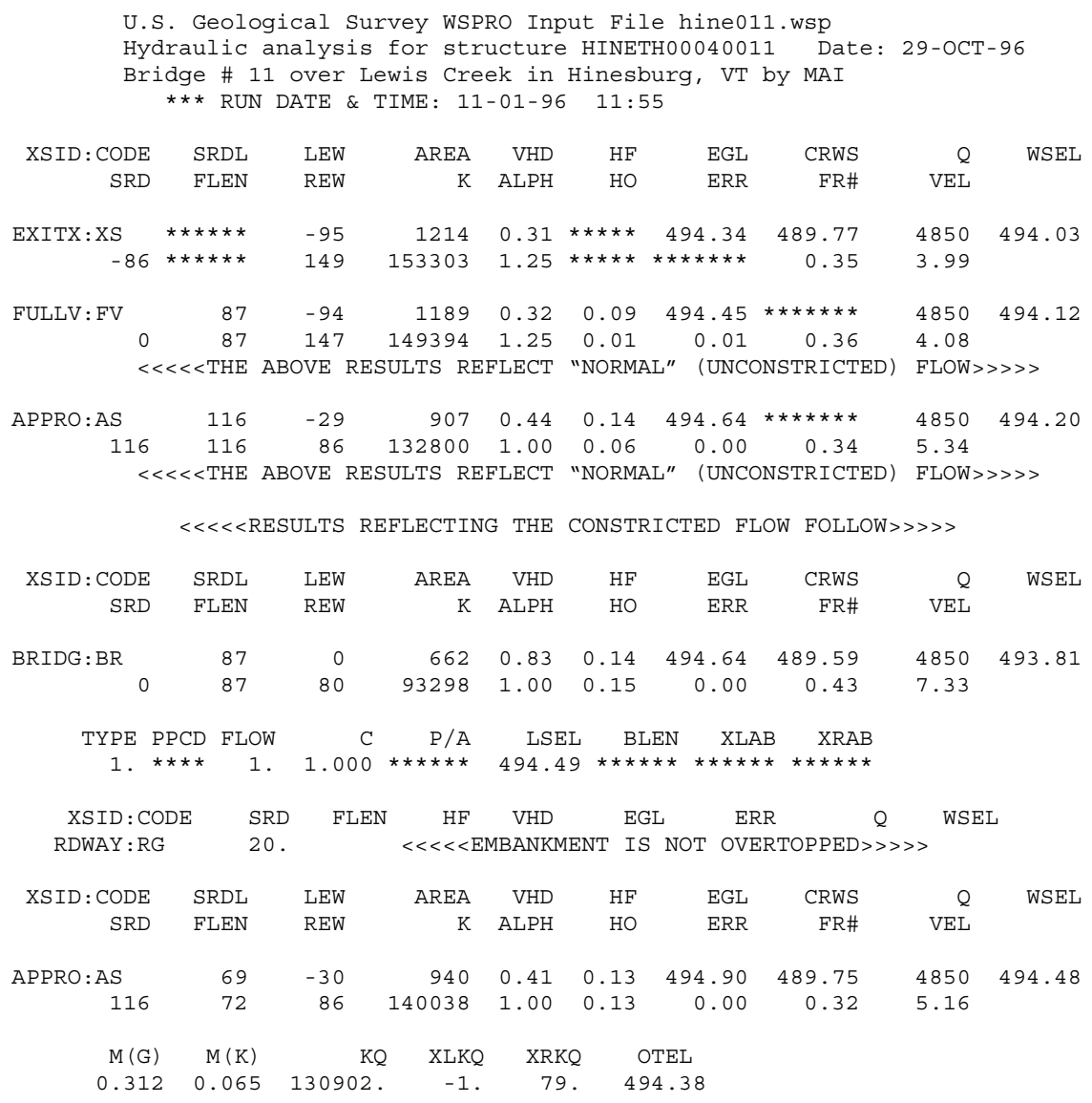

FIRST USER DEFINED TABLE.

\begin{tabular}{|c|c|c|c|c|c|c|c|c|}
\hline XSID : CODE & SRD & LEW & REW & $c$ & $\mathrm{~K}$ & AREA & VEL & WSEI \\
\hline EXITX:XS & -87 & -96 . & 149. & 4850. & 153303. & 1214 . & 3.99 & 494.03 \\
\hline FULLV : FV & 0. & -95. & 147. & 4850. & 149394. & 1189. & 4.08 & 494.12 \\
\hline BRIDG : BR & 0 . & 0 . & 80 . & 4850. & 93298 . & 662 & 7.33 & 493.81 \\
\hline RDWAY : RG & \multicolumn{3}{|c|}{ 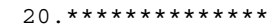 } & \multicolumn{3}{|c|}{ 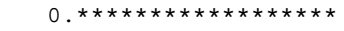 } & \multicolumn{2}{|c|}{$1.00 * * * * * * * *$} \\
\hline APPRO : AS & 116. & -31 & 86 & 4850 . & 140038. & 940 & 5.16 & 494.48 \\
\hline XSID : CODE & XLKQ & XRKQ & & & & & & \\
\hline APPRO : AS & -1 & 79. & 130902 & & & & & \\
\hline
\end{tabular}

SECOND USER DEFINED TABLE.

\begin{tabular}{|c|c|c|c|c|c|c|c|c|c|}
\hline XSID : CODE & CRWS & FR\# & YMIN & YMAX & $\mathrm{HF}$ & $\mathrm{HO}$ & VHD & EGL & WSEL \\
\hline EXITX:XS & 489.77 & 0.35 & 480.38 & $525.02 *$ & 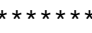 & $\star \star \star \star * *$ & 0.31 & 494.34 & 494.03 \\
\hline FULLV : FV & $\star * \star * * * * *$ & 0.36 & 480.57 & 525.21 & 0.09 & 0.01 & 0.32 & 4.45 & 494.12 \\
\hline BRIDG : BR & 489.59 & 0.43 & 480.49 & 495.26 & 0.14 & 0.15 & 0.83 & 494.64 & 493.81 \\
\hline RDWAY : RG & $\star \star \star \star * \star * \star * * \star * \star$ & $\star \star \star \star * *$ & 498.21 & $535.73 *$ & $\star \star \star \star \star \star \star *$ & $\star \star \star \star \star \star *$ & 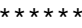 & & 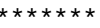 \\
\hline APPRO:AS & 489.75 & 0.32 & 481.00 & 527.13 & 0.13 & 0.13 & 0.41 & 494 & 494.4 \\
\hline
\end{tabular}


WSPRO OUTPUT FILE (continued)

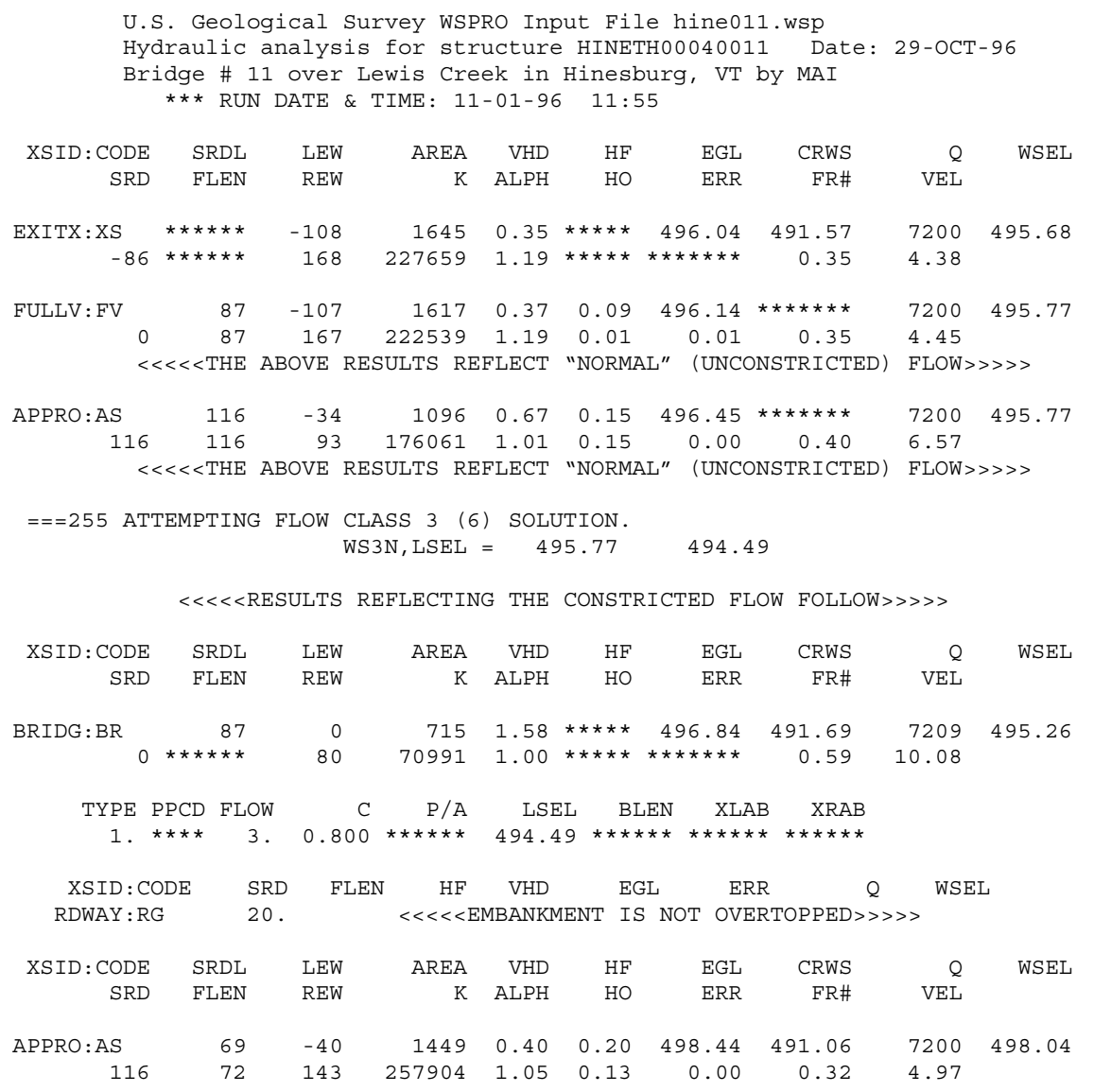

FIRST USER DEFINED TABLE.

$\begin{array}{lrrrrrrrr}\text { XSID : CODE } & \text { SRD } & \text { LEW } & \text { REW } & Q & \text { K } & \text { AREA } & \text { VEL } & \text { WSEL } \\ \text { EXITX : XS } & -87 . & -109 . & 168 . & 7200 . & 227659 . & 1645 . & 4.38 & 495.68 \\ \text { FULLV : FV } & 0 . & -108 . & 167 . & 7200 . & 222539 . & 1617 . & 4.45 & 495.77 \\ \text { BRIDG : BR } & 0 . & 0 . & 80 . & 7209 . & 70991 . & 715 . & 10.08 & 495.26 \\ \text { RDWAY : RG } & 20 . * * * * * * * * * * * * * & 0 . & 0 . & 0 . & 1.00 * * * * * * * \\ \text { APPRO:AS } & 116 . & -41 . & 143 . & 7200 . & 257904 . & 1449 . & 4.97 & 498.04\end{array}$

SECOND USER DEFINED TABLE.

\begin{tabular}{|c|c|c|c|c|c|c|c|c|c|}
\hline XSID : CODE & CRWS & FR\# & YMIN & YMAX & $\mathrm{HF}$ & $\mathrm{HO}$ & VHD & EGL & WSEL \\
\hline EXITX:XS & 491.57 & 0.35 & 480.38 & 525.02 * & $* * * * *$ & 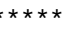 & 0.35 & 496.04 & 5.68 \\
\hline FULLV : FV & $\star * \star * * * * *$ & .35 & 80.57 & 25.21 & 0.09 & 0.01 & 0.37 & 496.14 & 77 \\
\hline BRIDG : BR & 491.69 & 0.59 & 480.49 & 495.26 * & $\star * * *$ & $* \star \star \star * *$ & 1.58 & 496.84 & 495.26 \\
\hline RDWAY : RG & $\star \star \star \star \star * \star * \star * \star * \star * \star *$ & 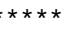 & 498.21 & 535.73 * & $* * * * *$ & 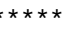 & 0.39 & $498.55 *$ & 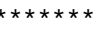 \\
\hline APPRO:AS & 491.06 & 0.32 & 481.00 & 527.13 & 0.20 & 0.13 & 0.40 & 498.44 & 498.04 \\
\hline
\end{tabular}




\section{APPENDIX C:}

\section{BED-MATERIAL PARTICAL-SIZE DISTRIBUTION}




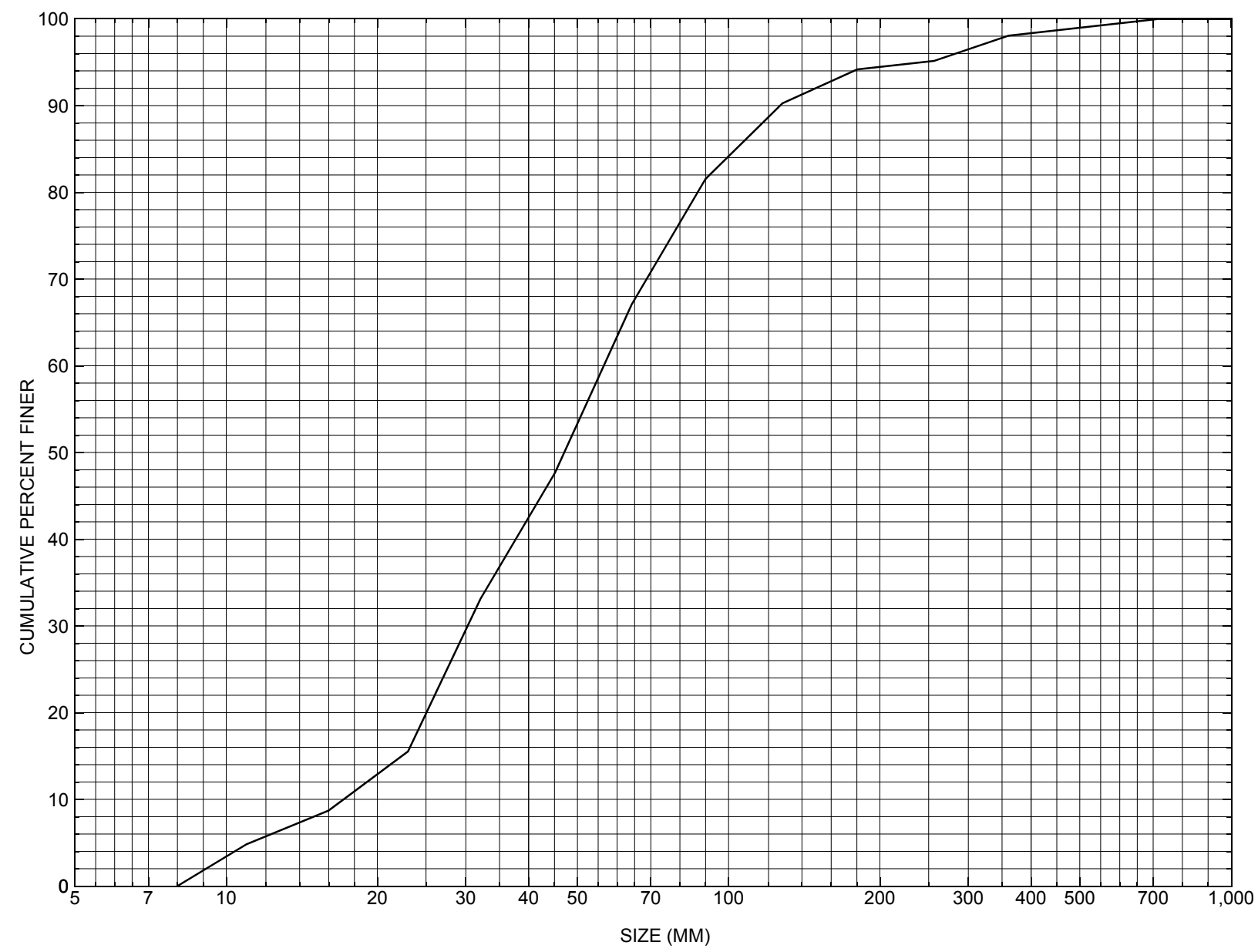

Appendix C. Bed material particle-size distribution for a pebble count in the channel approach of structure HINETH00040011, in Hinesburg, Vermont. 


\section{APPENDIX D: \\ HISTORICAL DATA FORM}




\section{Structure Number HINETH000400011}

\section{General Location Descriptive}

Data collected by (First Initial, Full last name) $\underline{\mathbf{L}}$. Medalie

Date $(M M / D D / Y Y)+12 / 15 / \underline{95}$

Highway District Number (I - 2; nn) $\mathbf{0 5}$

Town (FIPS place code; I - 4; nnnnn) $\mathbf{3 3 4 7 5}$

Waterway ( $($ - 6) LEWIS CREEK

Route Number TR 04

Topographic Map Hinesburg

Latitude (I - 16; nnnn.n) $\underline{\mathbf{4 4 1 7 0}}$
County (FIPS county code; I - 3; nnn)

Mile marker (I - 11; nnn.nnn) $\mathbf{0 0 0 2 9 0}$

Road Name ( $($ - 7): FAS 199

Vicinity (I - 9) 3.1 MI SOUTH JCT. VT.116

Hydrologic Unit Code: 2010002

Longitude (i - 17; nnnnn.n) $\mathbf{7 3 0 6 5}$

\section{Select Federal Inventory Codes}

FHWA Structure Number (I - 8) $\mathbf{2 0 0 1 9 9 0 0 1 1 0 4 0 7}$

Maintenance responsibility $(I-21 ; n n) \_\mathbf{0 3}$

Year built (I - 27; YYYY) 1983

Average daily traffic, ADT (I - 29; nnnnnn) $\underline{\mathbf{0 0 2 8 8 0}}$

Year of ADT (I - 30; YY) $\mathbf{9 1}$

Opening skew to Roadway $(I-34 ; n n) \quad 15$

Operational status $(I-41 ; X) \quad \mathbf{A}$

Structure type (I - 43; nnn) $\mathbf{3 0 2}$

Approach span structure type $(I-44 ; n n n) \quad \mathbf{0 0 0}$

Number of spans (I - 45; nnn)

Number of approach spans (I - 46; nnnn) $\mathbf{0 0 0 0}$ Comments:

The structure is a steel beam bridge with a concrete deck.
Maximum span length (I - 48; nnnn) $\underline{\mathbf{0 0 8 2}}$

Structure length (I - 49; nnnnnn) $\underline{\mathbf{0 0 0 0 8 4}}$

Deck Width (I - 52; nn.n) 316

Channel \& Protection $(I-61 ; n) \underline{8}$

Waterway adequacy $(I-71 ; n) \underline{8}$

Underwater Inspection Frequency (I - 92B; XYY) _ N

Year Reconstructed (I - 106) $\mathbf{0 0 0 0}$

Clear span (nnn.nft) $\mathbf{8 2}$

Vertical clearance from streambed (nnn.nft) 12

Waterway of full opening (nnn.n $\left.\mathrm{ft}^{2}\right) \mathbf{9 8 4}$ 


\section{Bridge Hydrologic Data}

Is there hydrologic data available? $\underline{\mathbf{Y}}$ if No, type ctrl-n $h \quad$ VTAOT Drainage area $\left(m i^{2}\right): 38.4$

Terrain character:

Stream character \& type:

Streambed material:

Discharge Data (cfs):

$$
\mathrm{Q}_{2.33} \frac{1150}{\mathbf{4 6 0 0}}
$$

$Q_{10} \frac{\mathbf{2 7 0 0}}{\mathbf{5 6 0 0}}$

$\mathrm{Q}_{25} \mathbf{3 6 0 0}$

$\mathrm{Q}_{500}$

Record flood date ( $M M / D D / Y Y$ ): I

Water surface elevation $(f t)$ :

Estimated Discharge (cfs): Velocity at $\mathrm{Q}$ $(\mathrm{ft} / \mathrm{s})$ :

Ice conditions (Heavy, Moderate, Light) : Debris (Heavy, Moderate, Light):

The stage increases to maximum highwater elevation (Rapidly, Not rapidly):

The stream response is (Flashy, Not flashy):

Describe any significant site conditions upstream or downstream that may influence the stream's stage:

Watershed storage area (in percent): $\%$

The watershed storage area is: (1-mainly at the headwaters; 2- uniformly distributed; 3-immediatly upstream oi the site)

Water Surface Elevation Estimates for Existing Structure:

\begin{tabular}{|l|l|c|c|c|c|}
\hline Peak discharge frequency & $Q_{2.33}$ & $Q_{10}$ & $Q_{25}$ & $Q_{50}$ & $Q_{100}$ \\
Water surface elevation (ft)) & $\mathbf{4 8 9 . 2}$ & $\mathbf{4 9 2}$ & $\mathbf{4 9 3 . 2}$ & $\mathbf{4 9 4 . 4}$ & $\mathbf{4 9 5 . 4}$ \\
Velocity (ft/sec) & & & & & \\
\hline
\end{tabular}

Long term stream bed changes:

Is the roadway overtopped below the $\mathrm{Q}_{100}$ ? (Yes, No, Unknown):

Frequency:

Relief Elevation ( $f t)$ :

Discharge over roadway at $Q_{100}\left(f t^{3} / \mathrm{sec}\right)$ :

Are there other structures nearby? (Yes, No, Unknown): Upstream distance (miles): Town: If No or Unknown, type ctrl-n os

Highway No. : Structure No. : Year Built:

Clear span (ft): Clear Height (ft): Structure Type: Full Waterway $\left(t^{2}\right)$ : 
Downstream distance (miles): Town: Year Built:

Highway No. : Structure No. : Structure Type:

Clear span (ft): Clear Height (ft): Full Waterway $\left(f^{2}\right)$ :

Comments:

Tailwater depth @ Q 25=8.7'; velocity @ Q 25=9.1 fps.

\section{USGS Watershed Data}

Watershed Hydrographic Data

Drainage area $(D A) \stackrel{38.41}{3 \mathrm{mi}^{2}}$

Watershed storage (ST)

Bridge site elevation $\mathbf{3 4 0} \mathrm{ft}$ $\%$

Main channel length $\mathbf{1 9 . 2 6}$ $\mathrm{mi}$

$10 \%$ channel length elevation 420

Lake and pond area

0.09 $\mathrm{mi}^{2}$

Main channel slope

(S) 44.31 $\mathrm{ft} / \mathrm{mi}$ Headwater elevation $\_\mathbf{2 2 5 0} \mathrm{ft}$

Watershed Precipitation Data

Average site precipitation in

Average headwater precipitation in

Maximum 2yr-24hr precipitation event $(124,2)$ in

Average seasonal snowfall (Sn) $\mathrm{ft}$ 


\section{Bridge Plan Data}

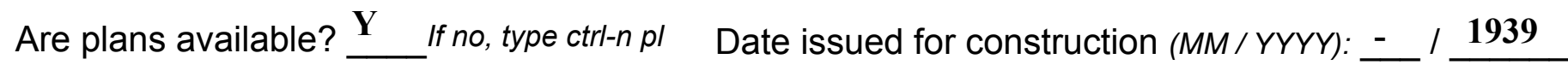
Project Number BHS 0199 (1) Minimum channel bed elevation:

Low superstructure elevation: USLAB DSLAB USRAB DSRAB Benchmark location description:

BM \#1, assumed elevation, 500 feet, at corner of left abutment and downstream wingwall. BM \#2, assumed elevation, 504.66 feet, on 24 inch elm, S.I.R., near upstream edge of road, 300 feet to north (right) of bridge.

Reference Point (MSL, Arbitrary, Other): Arbitrary Datum (NAD27, NAD83, Other):

Foundation Type: 1

If 1: Footing Thickness ___ Footing bottom elevation: 490

If 2: Pile Type: (1-Wood; 2-Steel or metal; 3-Concrete) Approximate pile driven length:

If 3: Footing bottom elevation:

Is boring information available? $\underline{\mathbf{Y}}$ If no, type ctrl-n bi Number of borings taken: $\underline{\mathbf{2}}$

Foundation Material Type: 1 (1-regolith, 2-bedrock, 3-unknown)

Briefly describe material at foundation bottom elevation or around piles:

Bottom of the right abutment is in sandy silt, at 490 feet.

Bottom of the left abutment is in sandy gravel at $\mathbf{4 8 8 . 5}$ feet.

Comments: 


\section{Cross-sectional Data}

Is cross-sectional data available? $\mathbf{N}$ If no, type ctrl-n xs

Source (FEMA, VTAOT, Other)? -

Comments: NO CROSS SECTIONAL INFORMATION

\begin{tabular}{|l|l|l|l|l|l|l|l|l|l|l|l|}
\hline Station & & - & - & - & - & - & - & - & - & - & - \\
\hline Feature & - & - & - & - & - & - & - & - & - & - & - \\
\hline $\begin{array}{l}\text { Low cord } \\
\text { elevation }\end{array}$ & - & - & - & - & - & - & - & - & - & - & - \\
\hline $\begin{array}{l}\text { Bed } \\
\text { elevation }\end{array}$ & - & - & - & - & - & - & - & - & - & - & - \\
\hline $\begin{array}{l}\text { Low cord to } \\
\text { bed length }\end{array}$ & - & - & - & - & - & - & - & - & - & - & - \\
\hline Station & - & - & - & - & - & - & - & - & - & - & - \\
\hline Feature & - & - & - & - & - & - & - & - & - & - & - \\
\hline $\begin{array}{l}\text { Low cord } \\
\text { elevation }\end{array}$ & - & - & - & - & - & - & - & - & - & - & - \\
\hline $\begin{array}{l}\text { Bed } \\
\text { elevation }\end{array}$ & - & - & - & - & - & - & - & - & - & - & - \\
\hline $\begin{array}{l}\text { Low cord to } \\
\text { bed length }\end{array}$ & - & - & - & - & - & - & - & - & - & - & - \\
\hline
\end{tabular}

Source (FEMA, VTAOT, Other)?

Comments: -

\begin{tabular}{|l|l|l|l|l|l|l|l|l|l|l|l|}
\hline Station & & - & - & - & - & - & - & - & - & - & - \\
\hline Feature & - & - & - & - & - & - & - & - & - & - & - \\
\hline $\begin{array}{l}\text { Low cord } \\
\text { elevation }\end{array}$ & - & - & - & - & - & - & - & - & - & - & - \\
\hline $\begin{array}{l}\text { Bed } \\
\text { elevation }\end{array}$ & - & - & - & - & - & - & - & - & - & - & - \\
\hline $\begin{array}{l}\text { Low cord to } \\
\text { bed length }\end{array}$ & - & - & - & - & - & - & - & - & - & - & - \\
\hline Station & - & - & - & - & - & - & - & - & - & - & - \\
\hline Feature & - & - & - & - & - & - & - & - & - & - & - \\
\hline $\begin{array}{l}\text { Low cord } \\
\text { elevation }\end{array}$ & - & - & - & - & - & - & - & - & - & - & - \\
\hline $\begin{array}{l}\text { Bed } \\
\text { elevation }\end{array}$ & - & - & - & - & - & - & - & - & - & - & - \\
\hline $\begin{array}{l}\text { Low cord to } \\
\text { bed length }\end{array}$ & - & - & - & - & - & - & - & - & - & - & - \\
\hline
\end{tabular}




\section{APPENDIX E: \\ LEVEL I DATA FORM}


U. S. Geological Survey

Bridge Field Data Collection and Processing Form

Qa/Qc Check by: $\underline{\text { EW Date: } 10 / 9 / 96}$

\section{Structure Number}

\section{A. General Location Descriptive}

1. Data collected by (First Initial, Full last name) $\mathbf{R}$. BURNS

2. Highway District Number $\mathbf{0 5}$

County CHITTENDEN (007)

Mile marker 000290

Waterway (I - 6) LEWIS CREEK

Route Number TH04

Town HINEBURG (33475)

Road Name FAS 199

3. Descriptive comments:

Hydrologic Unit Code: 2010002

Located 3.1 miles south of junction with VT 116.

\section{B. Bridge Deck Observations}

\section{Surface cover... $\quad$ LBUS $4 \quad$ RBUS $4 \quad$ LBDS $4 \quad$ RBDS 4 Overall 4}

(2b us,ds,lb,rb: 1- Urban; 2- Suburban; 3- Row crops; 4- Pasture; 5- Shrub- and brushland; 6- Forest; 7- Wetland)

5. Ambient water surface...US $\underline{2}$ UB $\underline{2}$ DS $\underline{2}$ (1-pool; 2- riffle)

6. Bridge structure type 1 (1- single span; 2- multiple span; 3- single arch; 4- multiple arch; 5-cylindrical culvert; 6- box culvert; or 7- other)
7. Bridge length 84
(feet)
Span length $\mathbf{8 2}$
(feet)
Bridge width $\underline{\mathbf{3 1 . 6}}$ (feet)

\section{Road approach to bridge:}
8. LB 2
RB 2
( 0 even, 1- lower, 2- higher)
9. LB_ 1
RB 1
(1- Paved, 2- Not paved)

10. Embankment slope (run / rise in feet / foot):

$$
\text { US left }
$$

2.0:1

US right

4.9:1

\begin{tabular}{|c|c|c|c|c|}
\hline & \multicolumn{2}{|c|}{ Protection } & \multirow{2}{*}{ 13.Erosion } & \multirow{2}{*}{ 14.Severity } \\
\hline & 11.Type & 12.Cond. & & \\
\hline LBUS & $\mathbf{0}$ & - & $\mathbf{0}$ & - \\
\hline RBUS & $\mathbf{0}$ & - & $\mathbf{0}$ & - \\
\hline RBDS & $\mathbf{0}$ & - & $\mathbf{0}$ & - \\
\hline LBDS & 1 & 1 & $\mathbf{0}$ & - \\
\hline
\end{tabular}

Bank protection types: 0- none; 1- < 12 inches;

2- < 36 inches; 3 - < 48 inches;

4- $<60$ inches; 5- wall / artificial levee

Bank protection conditions: 1- good; 2- slumped;

3- eroded; 4- failed

Erosion: 0 - none; 1- channel erosion; 2-

road wash; 3- both; 4- other

Erosion Severity: 0 - none; 1- slight; 2- moderate;

\section{Channel approach to bridge (BF):}

15. Angle of approach: $\mathbf{2 5}$

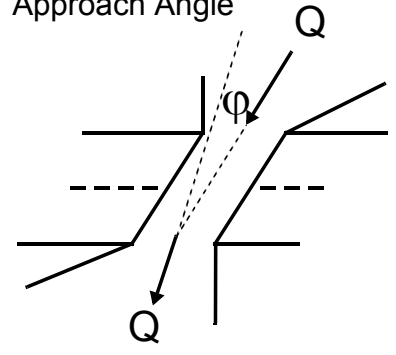

17. Channel impact zone 1 :

Where? LB $(L B, R B)$

Range? $\underline{25}$ feet $\underline{\text { DS }}$

Channel impact zone 2:

Where? RB (LB, RB)

Range? $\underline{\mathbf{3 0}}$ feet US

Impact Severity: 0- none to very slight; 1- Slight; 2- Moderate; 3- Severe
16. Bridge skew: 40 Bridge Skew Angle

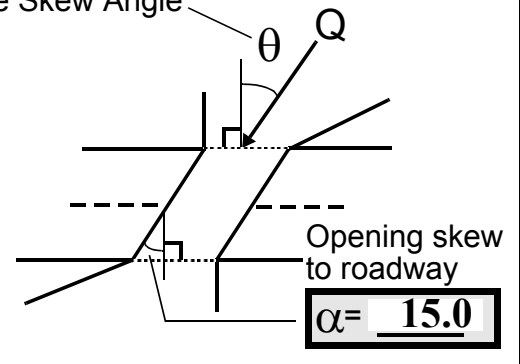

\section{Exist? $\mathbf{Y}(Y$ or $N)$}

Severity 2

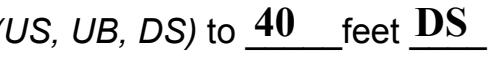

Exist? $\mathbf{Y}(Y$ or $N)$

Severity 1

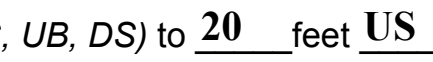


18. Bridge Type: $\mathbf{3}$

1a- Vertical abutments with wingwalls

1 b- Vertical abutments without wingwalls

2- Vertical abutments and wingwalls, sloping embankment Wingwalls perpendicular to abut. face

3- Spill through abutments

4- Sloping embankment, vertical wingwalls and abutments

Wingwall angle less than $90^{\circ}$.

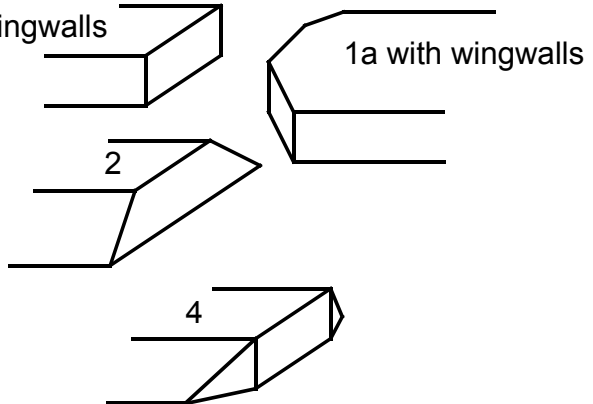

19. Bridge Deck Comments (surface cover variations, measured bridge and span lengths, bridge type variations, approach overflow width, etc.)

\#11: On the LBDS, there is a rock lined gully at the bottom of the road embankment. On the RBDS, the wingwall runs along the road embankment.

\#18: There is stone fill placed in front of the abutments and wingwalls forming a spill through abutment.

\section{Upstream Channel Assessment}

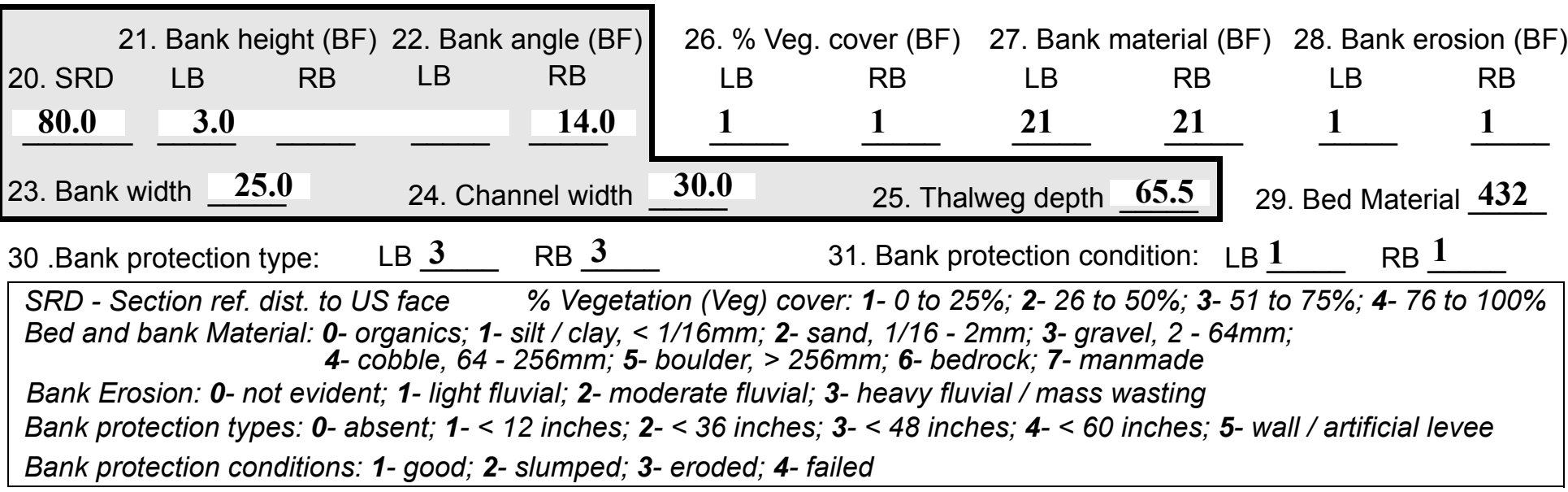

32. Comments (bank material variation, minor inflows, protection extent, etc.):

\#28: Both the left and right banks are scalloped with alternating clumps of grass and small cut-banks.

\#30: The bank protection extends from the upstream bridge face to 64 feet upstream along the left bank, and 17 feet upstream along the right bank. The bank protection is in front of the wingwalls and could be considered part of the spill through. 
33.Point/Side bar present? $\mathbf{N}(Y$ or $N$. if $N$ type ctrl-n pb)34. Mid-bar distance: -

35. Mid-bar width: -

36. Point bar extent: feet (US, UB) to feet (US, UB, DS) positioned $\%$ LB to $\% \mathrm{RB}$

37. Material: -

38. Point or side bar comments (Circle Point or Side; Note additional bars, material variation, status, etc.):

NO POINT BARS

39. Is a cut-bank present? $\underline{\mathbf{Y}}(\mathrm{Y}$ or if $N$ type $c t r-n c b)$

40. Where? $\mathbf{R B}$ (LB or RB)

41. Mid-bank distance: 32

42. Cut bank extent: 37

US, UB) to 26 feet $\underline{\mathbf{U S}}$ (US, UB, DS)

43. Bank damage: 1

(1- eroded and/or creep; 2- slip failure; 3- block failure)

44. Cut bank comments (eg. additional cut banks, protection condition, etc.):

There is another cut-bank on the upstream right bank from 120 feet upstream to 110 feet upstream, where the bank has been eroded.

A third cut-bank exists on the left bank from 193 feet upstream to 167 feet upstream. This cut-bank is also eroded.

45. Is channel scour present? $\mathbf{Y}$ (Y or if $N$ type ctrl-n cs) $\quad$ 46. Mid-scour distance: 114

47. Scour dimensions: Length $\underline{20}$ Width $\underline{4}$ Depth : $\underline{1} \quad$ Position $\underline{60} \%$ LB to $\underline{\mathbf{8 0}}$ \%RB

48. Scour comments (eg. additional scour areas, local scouring process, etc.):

There is also some local scouring behind boulders in stream.

49. Are there major confluences? $\mathbf{N}$ (Y or if $N$ type ctrl-n $m c)$

51. Confluence 1: Distance -

Confluence 2: Distance -

52. Enters on -

Enters on (LB or $R B)$ (LB or $R B)$

54. Confluence comments (eg. confluence name):

NO MAJOR CONFLUENCES
50. How many? -

53. Type(1- perennial; 2- ephemeral)

Type (1- perennial; 2- ephemeral)

\section{Under Bridge Channel Assessment}

55. Channel restraint (BF)? LB 2

56. Height (BF)
LB RB
$\mathbf{3 5 . 5}-$
58. Bank width (BF) -
(1- natural bank; 2- abutment; 3- artificial levee)

Bed and bank Material: 0- organics; 1- silt / clay, < 1/16mm; 2- sand, 1/16 - 2mm; 3- gravel, 2 - 64mm; 4- cobble, 64 - 256mm; 5- boulder, > 256mm; 6- bedrock; 7- manmade

Bank Erosion: 0- not evident; 1- light fluvial; 2- moderate fluvial; 3- heavy fluvial / mass wasting

64. Comments (bank material variation, minor inflows, protection extent, etc.):

543 
65. Debris and Ice Is there debris accumulation?

$(Y$ or $N)$ 66. Where? $\underline{Y}$

(1- Upstream; 2- At bridge; 3- Both)

67. Debris Potential $\underline{3}$

(1-Low; 2- Moderate; 3- High)

68. Capture Efficiency 1

(1-Low; 2- Moderate; 3- High)

69. Is there evidence of ice build-up? 1 ( $Y$ or $N)$

Ice Blockage Potential $\mathbf{N}$

(1-Low; 2- Moderate; 3- High)

70. Debris and Ice Comments:

1

There is some debris caught in the stone fill in front of the abutments and along the USRB.

\begin{tabular}{|l|c|c|c|c|c|c|c|c|}
\hline Abutments & $\begin{array}{c}\text { 71. Attack } \\
\angle \mathrm{BF})\end{array}$ & $\begin{array}{c}\text { 72. Slope } \\
(\mathrm{Qmax})\end{array}$ & $\begin{array}{l}\text { 73. Toe } \\
\text { loc. (BF) }\end{array}$ & $\begin{array}{c}\text { 74. Scour } \\
\text { Condition }\end{array}$ & $\begin{array}{c}\text { 75. Scour } \\
\text { depth }\end{array}$ & $\begin{array}{c}\text { 76. Exposure } \\
\text { depth }\end{array}$ & 77. Material & 78. Length \\
\hline LABUT & & - & $\mathbf{3 0}$ & $\mathbf{2}$ & $\mathbf{0}$ & - & - & $\mathbf{9 0 . 0}$ \\
\hline RABUT & $\mathbf{2 1}$ & $\mathbf{5}$ & $\mathbf{3 5}$ & & & $\mathbf{2}$ & $\mathbf{0}$ & $\mathbf{7 7 . 0}$ \\
\hline
\end{tabular}

Pushed: $L B$ or RB

Toe Location (Loc.): 0- even, 1- set back, 2- protrudes

Scour cond.: 0- not evident; 1- evident (comment); 2- footing exposed; 3-undermined footing; 4- piling exposed; 5- settled; 6- failed

Materials: 1- Concrete; 2- Stone masonry or drywall; 3- steel or metal; 4- wood

79. Abutment comments (eg. undermined penetration, unusual scour processes, debris, etc.):

$-$

21

The abutments are concrete and at 90 degrees for about 4 feet on the LABUT and 2 feet on the RABUT. At the toe of the vertical abutments, stone fill covers the bank slope to the stream channel and acts like a spill through abutment as described in the table above.

80. Wingwalls: $\begin{array}{lllll} & & & & \\ \text { Exist? Material? } & \text { Scour } & \text { Scour } & \text { Exposure } & \text { Angle? Length? } \\ & \text { Condition? depth? } & \text { depth? }\end{array}$

USLWW:

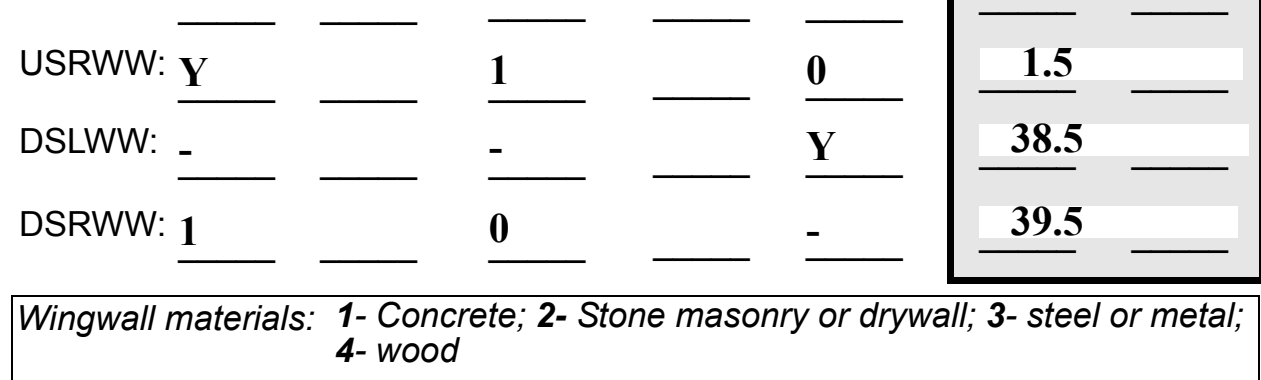


83. Wingwall and protection comments (eg. undermined penetration, unusual scour processes, etc.):

-
-
-
-
-
2
1
1
2
1
1

\section{Piers:}

84. Are there piers? Th (Y or if $N$ type ctrl-n pr)

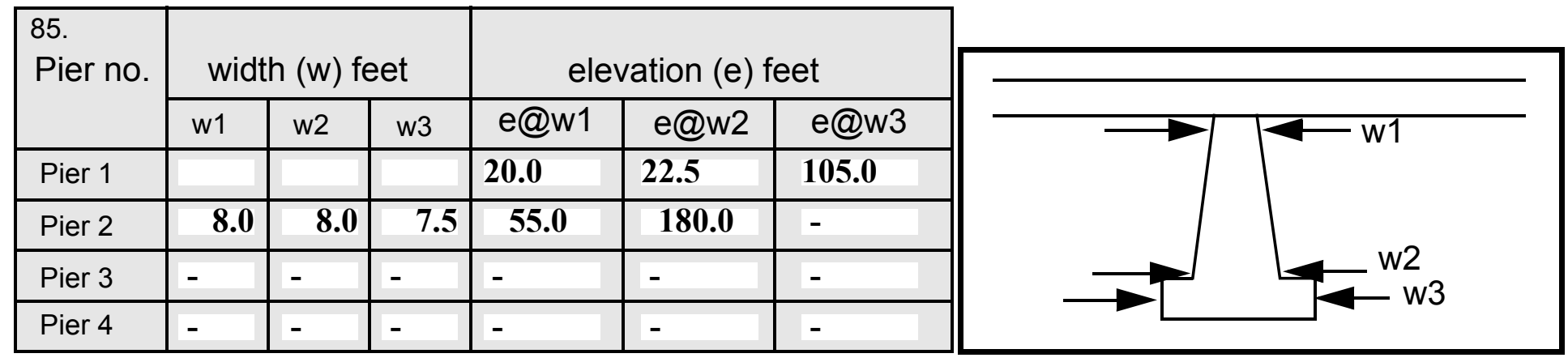

\begin{tabular}{|l|l|l|l|l|}
\hline Level 1 Pier Descr. & \multicolumn{1}{|c|}{1} & \multicolumn{1}{|c|}{2} & 3 & \multicolumn{1}{|l|}{} \\
\hline 86. Location (BF) & e & like & & - \\
\hline 87. Type & pro- & a & & - \\
\hline 88. Material & tec- & spill & & - \\
\hline 89. Shape & tion & thro & N & - \\
\hline 90. Inclined? & for & ugh. & - & - \\
\hline 91. Attack $\angle$ (BF) & the & & - & - \\
\hline 92. Pushed & abut & & - & - \\
\hline 93. Length (feet) & - & - & - & - \\
\hline 94. \# of piles & ment & & - & - \\
\hline 95. Cross-members & sand & & - & - \\
\hline 96. Scour Condition & wing & & - & - \\
\hline 97. Scour depth & walls & & - & - \\
\hline 98. Exposure depth & acts & & - & - \\
\hline
\end{tabular}

LFP, LTB, LB, MCL, MCM, MCR, RB, RTB, RFP

1- Solid pier, 2- column, 3- bent

1-Wood; 2- concrete; 3- metal; 4- stone

1- Round; 2- Square; 3- Pointed

Y-yes; $N-$ no

$L B$ or $R B$

0- none; 1- laterals; 2- diagonals; 3- both

0- not evident; 1- evident (comment);

2- footing exposed; 3- piling exposed;

4- undermined footing; 5- settled; 6-failed 
99. Pier comments (eg. undermined penetration, protection and protection extent, unusual scour processes, etc.):

-
-
-
-
-
-
-
-
-
-

100.

\section{E. Downstream Channel Assessment}

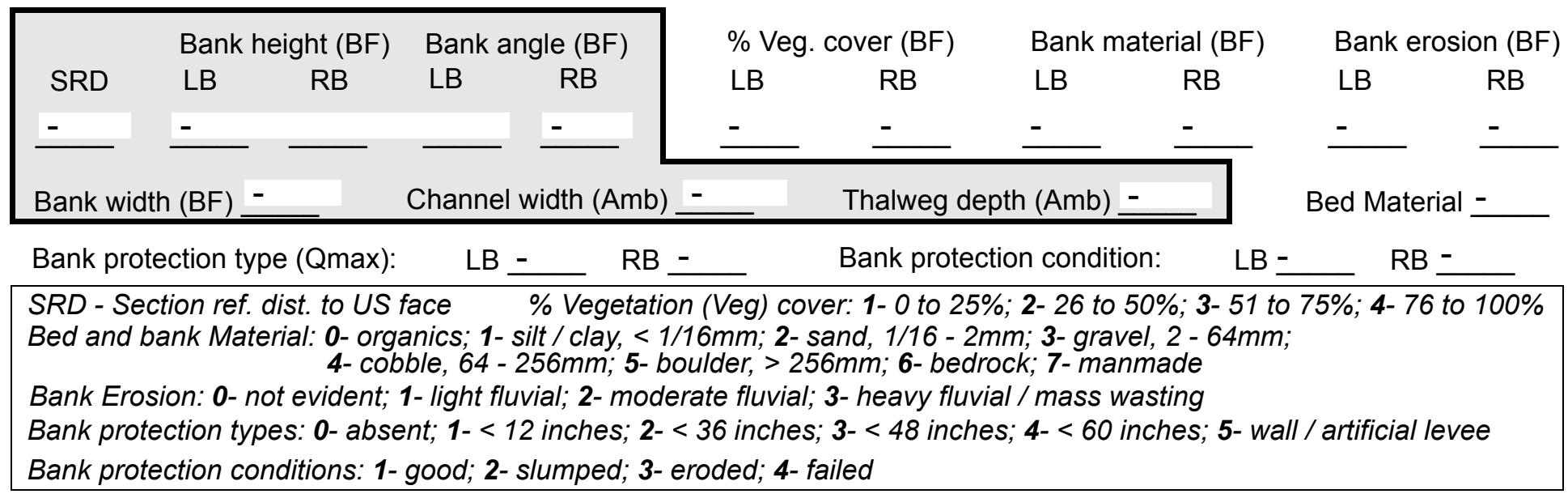

Comments (eg. bank material variation, minor inflows, protection extent, etc.):

-
-
-
-
-
-
-
NO PIERS

101. Is a drop structure present? ( $Y$ or $N$, if $N$ type ctrl-n ds)

102. Distance: - feet
103. Drop: - feet
104. Structure material:
(1- steel sheet pile; 2- wood pile; 3- concrete; 4- other)

105. Drop structure comments (eg. downstream scour depth):

1

1

2

2

1

1 
106. Point/Side bar present? $\mathbf{4 3}$ (Y or N. if N type ctrl-n pb)Mid-bar distance: $\mathbf{2}$

Mid-bar width: $\mathbf{3}$

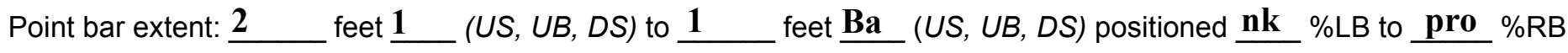

Material: tec

Point or side bar comments (Circle Point or Side; note additional bars, material variation, status, etc.):

tion on the left bank is in front of the wingwall and is part of the spill through abutments. Wingwall protection which goes from the bridge face to 10 feet downstream. Then, there is type 3 protection from 24 feet downstream to 80 feet downstream on the left bank.

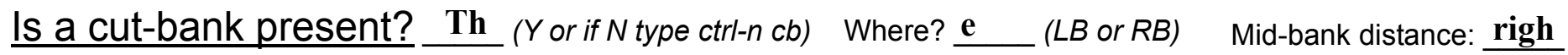
Cut bank extent: $\underline{\mathbf{t}}$ feet $\underline{\mathbf{b a}}$ (US, UB, DS) to nk feet pro (US, UB, DS)

Bank damage: tec- (1- eroded and/or creep; 2- slip failure; 3- block failure)

Cut bank comments (eg. additional cut banks, protection condition, etc.):

tion is from the bridge face to $\mathbf{4 7}$ feet downstream and is in front of the wingwall.

Like the upstream banks, both downstream banks are scalloped with alternating grass clumps and cut-banks.

Is channel scour present? ( $Y$ or if $N$ type ctrl-n cs)

Mid-scour distance:

Scour dimensions: Length Width Depth:

Positioned

$\%$ LB to $\% \mathrm{RB}$

Scour comments (eg. additional scour areas, local scouring process, etc.):

$\mathbf{N}$

$-$

NO DROP STRUCTURE

Are there major confluences? ( $Y$ or if $N$ type ctrl-n $m c$ )

How many?

Confluence 1: Distance Enters on (LB or $R B)$

Type $\mathbf{N}$ (1-perennial; 2- ephemeral)

Confluence 2: Distance -

Enters on (LB or RB)

Type (1-perennial; 2- ephemeral)

Confluence comments (eg. confluence name):

\section{F. Geomorphic Channel Assessment}

107. Stage of reach evolution -

1- Constructed

2- Stable

3- Aggraded

4- Degraded

5- Laterally unstable

6- Vertically and laterally unstable 
108. Evolution comments (Channel evolution not considering bridge effects; See HEC-20, Figure 1 for geomorphic descriptors):

$-$

$-$

-

NO POINT BARS

Y

RB

58

47

DS

68 


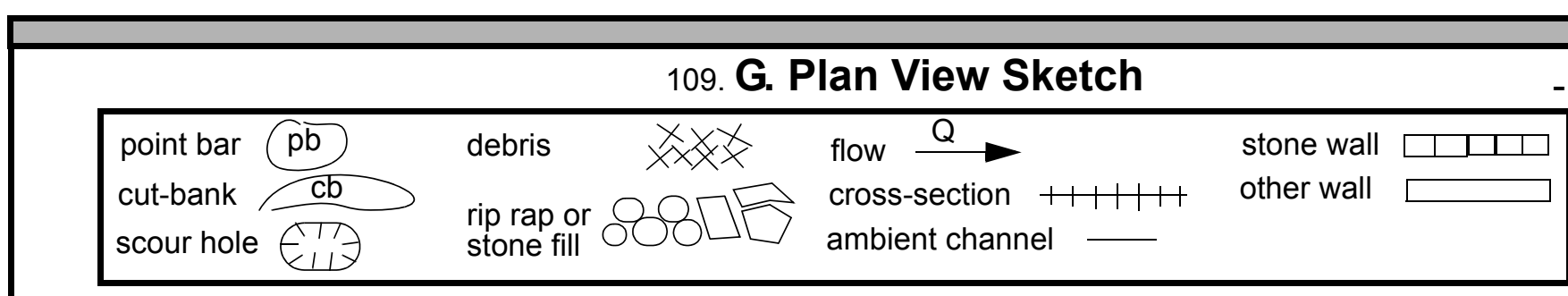

D

cut-bank

scour hole rip rap
stone fill cross-section $+1+1+1$ ambient channe other wall 
APPENDIX F:

SCOUR COMPUTATIONS 
SCOUR COMPUTATIONS

\begin{tabular}{|c|c|c|c|}
\hline Structure Number: HINETH00040011 & & Town: & Hinesburg \\
\hline Road Number: $\quad$ TH 4 & & County: & Chittenden \\
\hline Lewis Creek & & & \\
\hline Initials MAI & Checked: & EMB & \\
\hline Analysis of contraction scour, live & -bed or $\mathrm{cl}$ & ear wate & \\
\hline $\begin{array}{l}\text { Critical Velocity of Bed Material } \\
\mathrm{Vc}=11.21 * \mathrm{y}^{\wedge} 0.1667 * \mathrm{D} 50^{\wedge} 0.33 \text { with Ss }\end{array}$ & $\begin{array}{l}\text { converted } \\
=2.65\end{array}$ & to Engl: & sh units) \\
\hline (Richardson and others, 1995, p. 28 & eq. 16) & & \\
\hline Approach Section & & & \\
\hline Characteristic & $100 \mathrm{yr}$ & $500 \mathrm{yr}$ & other Q \\
\hline Total discharge, cfs & 4850 & 7200 & 0 \\
\hline Main Channel Area, ft2 & 625 & 842 & 0 \\
\hline Left overbank area, ft2 & 316 & 539 & 0 \\
\hline Right overbank area, ft2 & 0 & 69 & 0 \\
\hline Top width main channel, ft & 60 & 61 & 0 \\
\hline Top width L overbank, ft & 58 & 68 & 0 \\
\hline Top width $\mathrm{R}$ overbank, ft & 0 & 55 & 0 \\
\hline D50 of channel, ft & 0.1543 & 0.1543 & 0 \\
\hline D50 left overbank, ft & 0 & 0 & 0 \\
\hline D50 right overbank, ft & 0 & 0 & 0 \\
\hline Y1, average depth, MC, ft & 10.4 & 13.8 & ERR \\
\hline y1, average depth, LOB, ft & 5.4 & 7.9 & ERR \\
\hline Y1, average depth, ROB, ft & ERR & 1.3 & $\mathrm{ERR}$ \\
\hline Total conveyance, approach & 139986 & 257908 & 0 \\
\hline Conveyance, main channel & 91877 & 148213 & 0 \\
\hline Conveyance, LOB & 48109 & 104907 & 0 \\
\hline Conveyance, ROB & 0 & 4787 & 0 \\
\hline Percent discrepancy, conveyance & 0.0000 & 0.0004 & ERR \\
\hline Qm, discharge, MC, Cfs & 3183.2 & 4137.7 & ERR \\
\hline Q1, discharge, LOB, cfs & 1666.8 & 2928.7 & ERR \\
\hline Qr, discharge, ROB, Cfs & 0.0 & 133.6 & ERR \\
\hline Vm, mean velocity $\mathrm{MC}$, ft/s & 5.1 & 4.9 & ERR \\
\hline Vl, mean velocity, LOB, ft/s & 5.3 & 5.4 & ERR \\
\hline Vr, mean velocity, ROB, ft/s & ERR & 1.9 & ERR \\
\hline Vc-m, crit. velocity, $M C$, ft/s & 8.9 & 9.3 & $\mathrm{~N} / \mathrm{A}$ \\
\hline Vc-l, crit. velocity, LOB, ft/s & 0.0 & 0.0 & $\mathrm{~N} / \mathrm{A}$ \\
\hline Vc-r, crit. velocity, ROB, ft/s & $\mathrm{N} / \mathrm{A}$ & 0.0 & $\mathrm{~N} / \mathrm{A}$ \\
\hline Results & & & \\
\hline Live-bed(1) or Clear-Water(0) Contr & action $\mathrm{Sco}$ & our? & \\
\hline Main Channel & 0 & 0 & $\mathrm{~N} / \mathrm{A}$ \\
\hline ARMORING & & & \\
\hline D90 & 0.415 & 0.415 & \\
\hline D95 & 0.7967 & 0.7967 & \\
\hline
\end{tabular}


Critical grain size, Dc, ft Decimal-percent coarser than DC Depth to armoring, ft

$\begin{array}{lll}0.1556 & 0.2928 & \text { ERR } \\ 0.495 & 0.188 & \\ 0.48 & 3.79 & \text { ERR }\end{array}$

Clear water Contraction Scour in MAIN CHANNEL

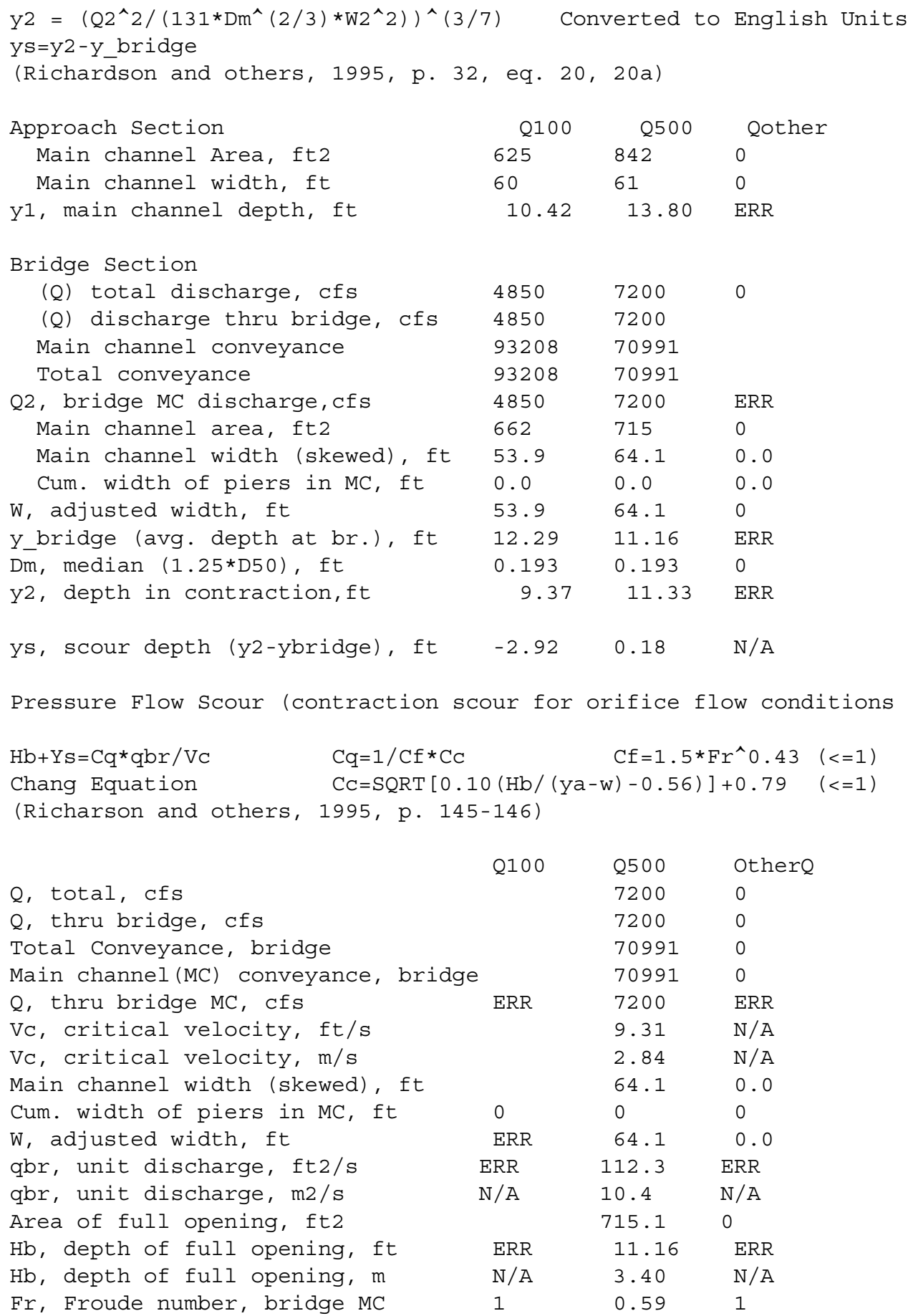




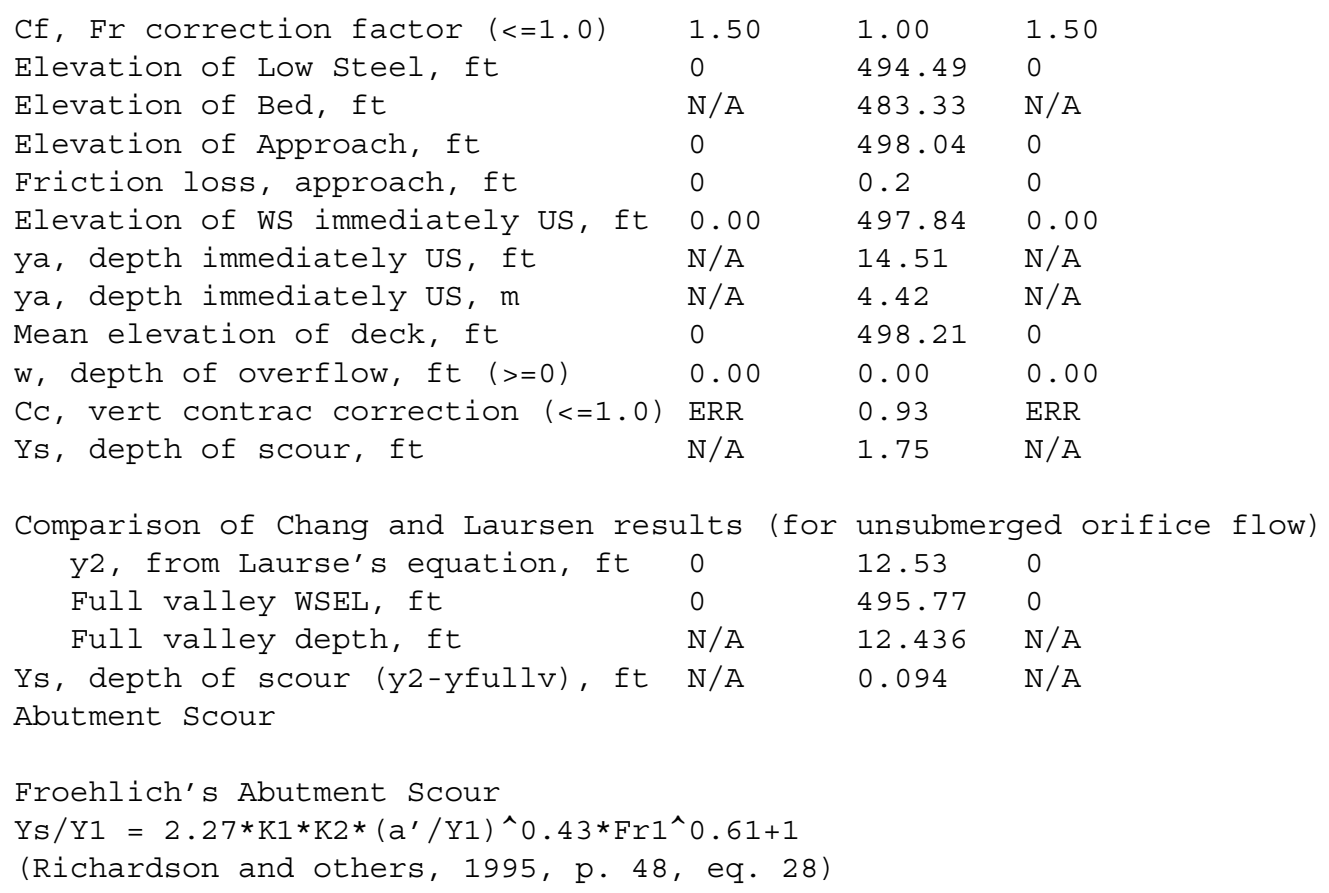




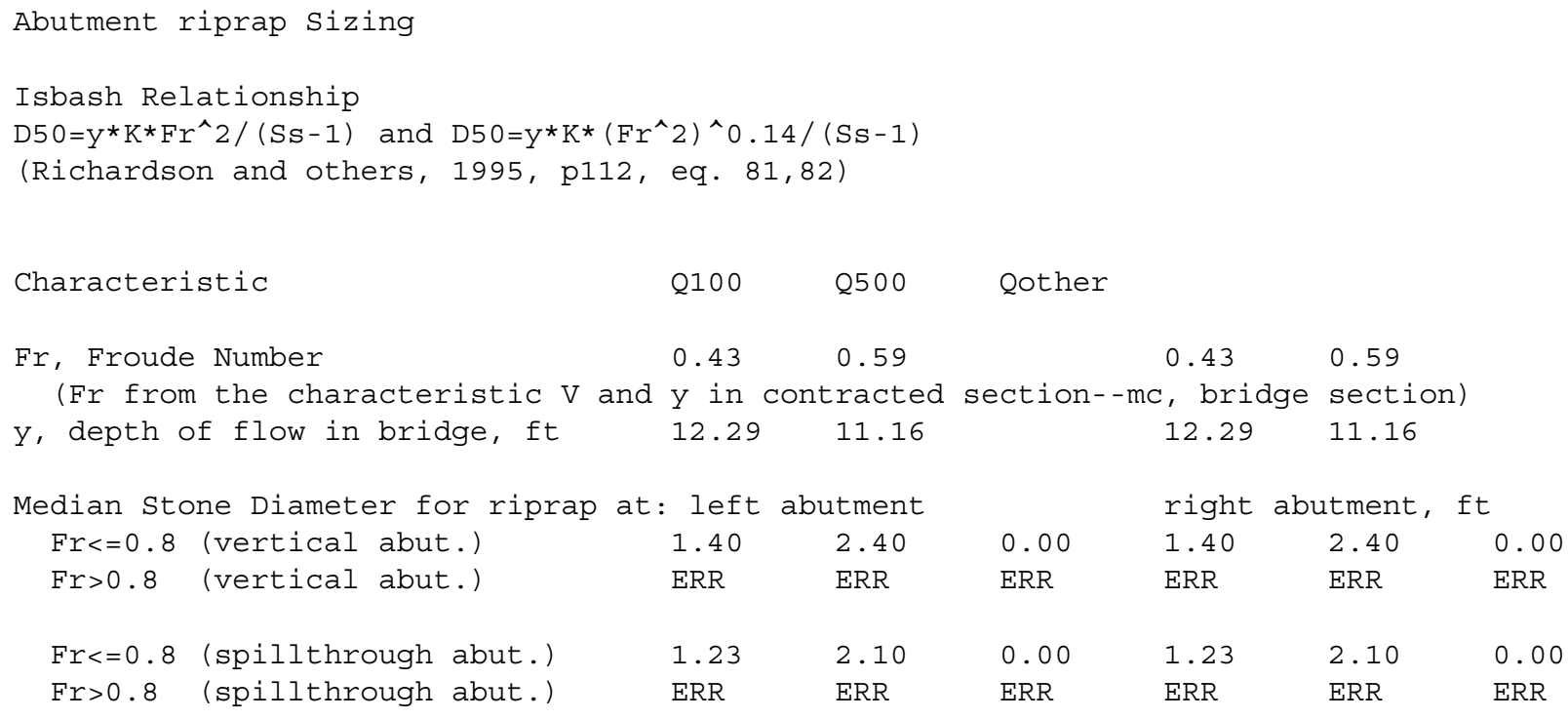

